\title{
MOLECULAR EVOLUTION OF GPCRS CRH/CRH receptors
}

\author{
David A Lovejoy', Belinda S W Chang ${ }^{1,2}$, Nathan R Lovejoy ${ }^{3}$ and Jon del Castillo ${ }^{1}$ \\ ${ }^{1}$ Department of Cell and Systems Biology, University of Toronto, 25 Harbord Street, Toronto, Ontario, \\ Canada L4A IK6 \\ ${ }^{2}$ Department of Ecology and Evolution, University of Toronto, Toronto, Ontario, Canada \\ ${ }^{3}$ Department of Life Sciences, University of Toronto Scarborough, Toronto, Ontario, Canada
}

Correspondence should be addressed to D A Lovejoy Email david.lovejoy@utoronto.ca

\begin{abstract}
Corticotrophin-releasing hormone $(\mathrm{CRH})$ is the pivotal neuroendocrine peptide hormone associated with the regulation of the stress response in vertebrates. However, $\mathrm{CRH}$-like peptides are also found in a number of invertebrate species. The origin of this peptide can be traced to a common ancestor of lineages leading to chordates and to arthropods, postulated to occur some 500 million years ago. Evidence indicates the presence of a single $\mathrm{CRH}$-like receptor and a soluble binding protein system that acted to transduce and regulate the actions of the early $\mathrm{CRH}$ peptide. In vertebrates, genome duplications led to the divergence of $\mathrm{CRH}$ receptors into $\mathrm{CRH} 1$ and $\mathrm{CRH} 2$ forms in tandem with the development of four paralogous ligand lineages that included $\mathrm{CRH}$; urotensin I/urocortin (Ucn), Ucn2 and Ucn3. In addition, taxon-specific genome duplications led to further local divergences in $\mathrm{CRH}$ ligands and receptors. Functionally, the $\mathrm{CRH}$ ligand-receptor system evolved initially as a molecular system to integrate early diuresis and nutrient acquisition. As multicellular organisms evolved into more complex forms, this ligand-receptor system became integrated with the organismal stress response to coordinate homoeostatic challenges with internal energy usage. In vertebrates, $\mathrm{CRH}$ and the $\mathrm{CRH} 1$ receptor became associated with the hypothalamo-pituitary-adrenal/interrenal axis and the initial stress response, whereas the $\mathrm{CRH} 2$ receptor was selected to play a greater role in diuresis, nutrient acquisition and the latter aspects of the stress response.
\end{abstract}

Key Words
- stress
Metazoa
- diuresis
- energy metabolism
- reproduction
- CNS

Journal of Molecular Endocrinology (2014) 52, T43-T60

\section{Introduction}

The evolution of the corticotrophin-releasing hormone (CRH) family of peptides and their cognate receptors provides a model to understand peptide ligand and receptor co-evolution. Over the last few years with the acquisition of genomic data from many metazoan species, our understanding of the CRH ligand-receptor system has become much clearer. It has subsequently allowed us to explain as to why ligand gene duplications do not necessarily corroborate with receptor gene duplications. In addition, such studies help establish how physiological functions, associated with gene expansion events in vertebrates, relate to the ancestral invertebrate genomes. With respect to $\mathrm{CRH}$ physiology, these genomic studies explain as to why peptides, initially associated with diuresis and feeding, become associated with the stress response as we know it. Thus, the goal of this review is to

Published by Bioscientifica Ltd.

This paper is one of eight papers that form part of a thematic review section on the Molecular Evolution of GPCRs. The Guest Editor for this section was Hubest/Vaudry $2: 08: 08 \mathrm{PM}$ European Institute for Peptides Research, University of Rouen, France. via free access 
understand the evolutionary history and functional expansion of the CRH receptors, and why two such receptor paralogues have become selected for the regulation of the stress response in vertebrates, where four ligand paralogues exist.

Elucidation of the CRH family and its receptors has its origins with the earliest forays into our understanding of neuroendocrinology in the first part of the 20th century. Its history is intrinsically tied to the understanding of receptor-ligand interaction and gene duplication paradigms (Lovejoy \& Balment 1999, Lovejoy 2005, 2009, Lovejoy \& Jahan 2006). However, establishing a universal approach to receptor-ligand structure and function in the current scientific environment requires some reconciliation with two complementary, yet frequently misunderstood, philosophical approaches. On one hand, a comparative and evolutionary approach, where structure-function studies were carried out using many species across the Metazoa, provides an understanding of the origin, conservation and evolution of the receptorligand system in question. On the other hand, should a particular ligand-receptor system have applications to human health then, a research approach that utilises fewer species that act as models to understand human health and pathology is typically initiated. The scientific goals of both approaches are essentially similar; however, the terminology used may generate confusion among researchers associated with either approach. In this review, we have focused on the first approach utilising biomedical research insofar as it helps establish the reasons for the origin, evolution and function of the CRH receptors.

The evolution and function of vertebrate neuroendocrine pathways are complex. The effect of speciation throughout many niches and habitats, coupled with widespread gene and genome expansion events, has led to the formation of functionally related paralogous ligands and receptors, as well as divergent orthologues. Thus, the delineation of a single neuroendocrine pathway can be a daunting task. The classical interpretation is that the ligand and its receptor arguably play the greatest role in determining the specificity of action. However, because of the relative structural simplicity of a ligand in comparison to its receptor, historically, the discovery and structural characterisation of the ligand have preceded the elucidation of the receptor mechanism. As with most neuroendocrine systems, the discovery, structural characterisation and functional attributes of the CRH receptors occurred later than the onset of the CRH ligand discoveries.

Early attempts at the purification of receptors provided limited information on their structures.
G-protein-coupled receptors (GPCRs) are particularly difficult to solubilise and isolate because of their complex association with the plasma membrane. Thus, it was not until the advent of mRNA isolation and cloning methods could these receptors be characterised. Although the first CRH-related ligand was discovered in 1979 (Montecucchi et al. 1979), it was not until Chen et al. (1993) in Wylie Vale's laboratory elucidated the structure of the first CRH receptor. Since then, the identification of many CRH paralogues and orthologues, combined with the pharmacological and physiological evaluation of their actions with the additional modern genome sequencing methods, has led to a detailed model of CRH receptor structural and functional evolution.

\section{Discovery, evolution and function of CRH peptides}

The first CRH, per se, purified from sheep hypothalami was described in a work published by Wylie Vale and associates in 1981, well after the initial evidence that provided its existence in 1955 was reported (Guillemin \& Rosenberg 1955 , Schally \& Saffran 1955). However, a few years before the report of the CRH structure, Montecucchi et al. (1979) identified the structure of sauvagine (SVG), a 41-kDa peptide isolated from the skin of neotropical frog (Phyllomedusa sauvagei). Later, a similar peptide was characterised in the urophysis of a fish species (white sucker, Catostomus commersoni) and was called urotensin I (UI; Lederis et al. 1982) so as to distinguish it from UII that was also found in the urophysis but structurally unrelated to the CRH family of peptides. Both UI and SVG were shown to be effective at stimulating ACTH release from the rat pituitary gland although their pharmacological profiles differed from that of CRH (see Lovejoy \& Balment (1999) and Lovejoy (2009) for reviews). As a result, these peptides became important tools in the identification of the pharmacological properties of the CRH receptors once they were discovered. The mammalian orthologue of UI and SVG was reported in 1995 (Vaughan et al. 1995) and was named urocortin (Ucn), thus confirming the conservation of two paralogous CRH-like peptides in the vertebrates (see Lovejoy \& Balment (1999)). However, it is important to note that, from an evolutionary perspective, UI and Ucn are paralogues of $\mathrm{CRH}$, and physiologically, they should be treated as such, rather than grouping them with the later discovered Ucn2 and Ucn3 (Fig. 1).

In 1989, a peptide hormone associated with diuresis in the tobacco hornworm (Manduca sexta; Kataoka et al. 1989) was characterised and showed remarkable structural

Published by Bioscientifica Lto 
Corticotrophin-releasing hormone Urocortin

(NM000756)

(NM003353)

Urocortin 2

Urocortin 3
(BC022096)

(NM053049)

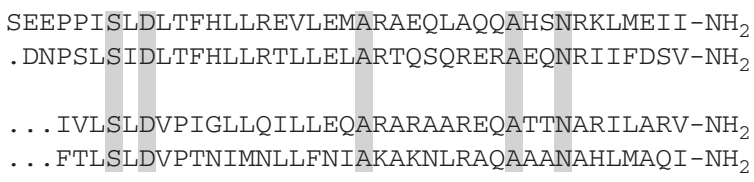

SEEPPISLDLTFHLLREVLEMARAEQLAQQAHSNRKLMEII-NH $\mathrm{N}_{2}$

... IVLSLDVPIGLLQILLEQARARAAREQATTNARILARV-NH

. . FTLSLDVPTNIMNLLFNIAKAKNLRAQAAANAHLMAQI- $\mathrm{NH}_{2}$

Figure 1

Human CRH paralogues. CRH and urocortin consist of one paralogous lineage, whereas urocortins 2 and 3 comprise the second paralogous lineage in chordates.

similarity to the CRH peptides, notably SVG. Its high degree of residue identity indicated that it was homologous to the vertebrate CRH. This discovery was followed by additional reports of orthologous CRH-like peptides, collectively referred to as the diuretic hormones (DHs), in insects (Coast 1998, 2007). However, these peptides shared significant structural similarity with all of the vertebrate CRH paralogues with no clear evidence of separate CRH and UI/Ucn forms (Lovejoy \& Jahan 2006). This mystery was resolved with the characterisation of a peptide with structural similarity to the vertebrate CRH and Ucns on one hand and the insect DHs on the other in the tunicates, Ciona intestinalis and C. savignyi (Lovejoy \& Barsyte-Lovejoy 2010). As the tunicates (urochordates) are the evolutionarily closest sister lineage to the Chordata (Delsac et al. 2006), this report supported the concept that only a single CRH peptide was inherited by the ancestral vertebrates. Further studies (see below) indicate that this peptide was not initially involved in a vertebrate-like 'hypothalamus-pituitary-adrenal/interrenal (HPA/I)'-like axis.

In vertebrates, as postulated by the $2 \mathrm{R}$ hypothesis, which stated that there were two rounds of genome duplication at the base of vertebrate evolution, four CRH paralogues should exist (Dehal \& Boore 2005), if there was a single CRH-like gene inherited. The independent work of the Vale (Lewis et al. 2001, Reyes et al. 2001) and Hsueh laboratories (Hsu \& Hseuh 2001) confirmed this with the characterisation of Ucn2 (stresscopin) and Ucn3 (stresscopin-like peptide) (Fig. 1). Further characterisation of $\mathrm{CRH}$ paralogues in vertebrates has confirmed the presence of four CRH-like peptide genes among jawed vertebrates, although Ucn2 appears to be non-functional in the elephant shark (Callorhinchus milii; Nock et al. 2011) and chimpanzee (Ikemoto \& Park 2006) because of the lack of conserved initiation codons, suggesting that the prohormones are not produced. Indeed, the strong structural similarity between Ucn 2 and Ucn 3 has led to the interpretation that one or more of the functions of Ucn2 have been taken over by Ucn3 in these species. Nevertheless, studies on the expression of CRH peptides in the
Metazoa indicated that a single form was inherited by the basal vertebrates when the first genome duplication led to the formation of a CRH/UI/Ucn ancestral peptide on one hand and a Ucn $2 / 3$ ancestral peptide on the other hand. The second duplication event led to the formation of the four individual peptides (Lovejoy \& Jahan 2006, Lovejoy 2009, Lovejoy \& de Lannoy 2013; Figs 2 and 3). Further, all four peptide genes are found on different chromosomes (see Lovejoy (2012)), consistent with the original hypothesis of the relationship between chromosomal and paralogon duplication and the 2R hypothesis (Lundin 1993, Holland et al. 1994, Holland 1999, Delsac et al. 2006).

\section{Description of CRH family of peptides and their functions}

Studies conducted primarily in insect models, where only a single CRH-like peptide (DHs) is present, suggest that the earliest function of the peptide family was associated with diuresis and feeding (Kataoka et al. 1989, Audsley et al. 1997, Coast 2007, 1998). Given the phylogenetic age of the CRH peptides, this is not surprising. In early metazoans, because of their less complex physiology and genome, extracellular regulatory systems were ultimately tied to the coordination of energy production to survival with respect to feeding, digestion, diuresis and defence

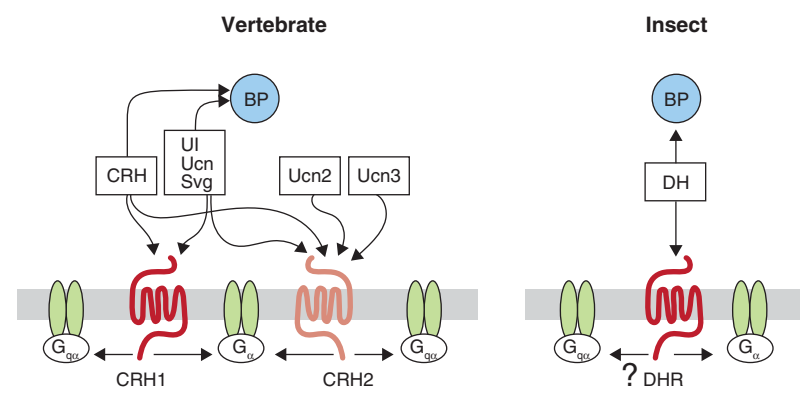

Figure 2

Scheme of the molecular interaction among CRH ligands, receptors and the binding protein in chordates and insects. See text for discussion.

Published by Bioscientifica Ltd 


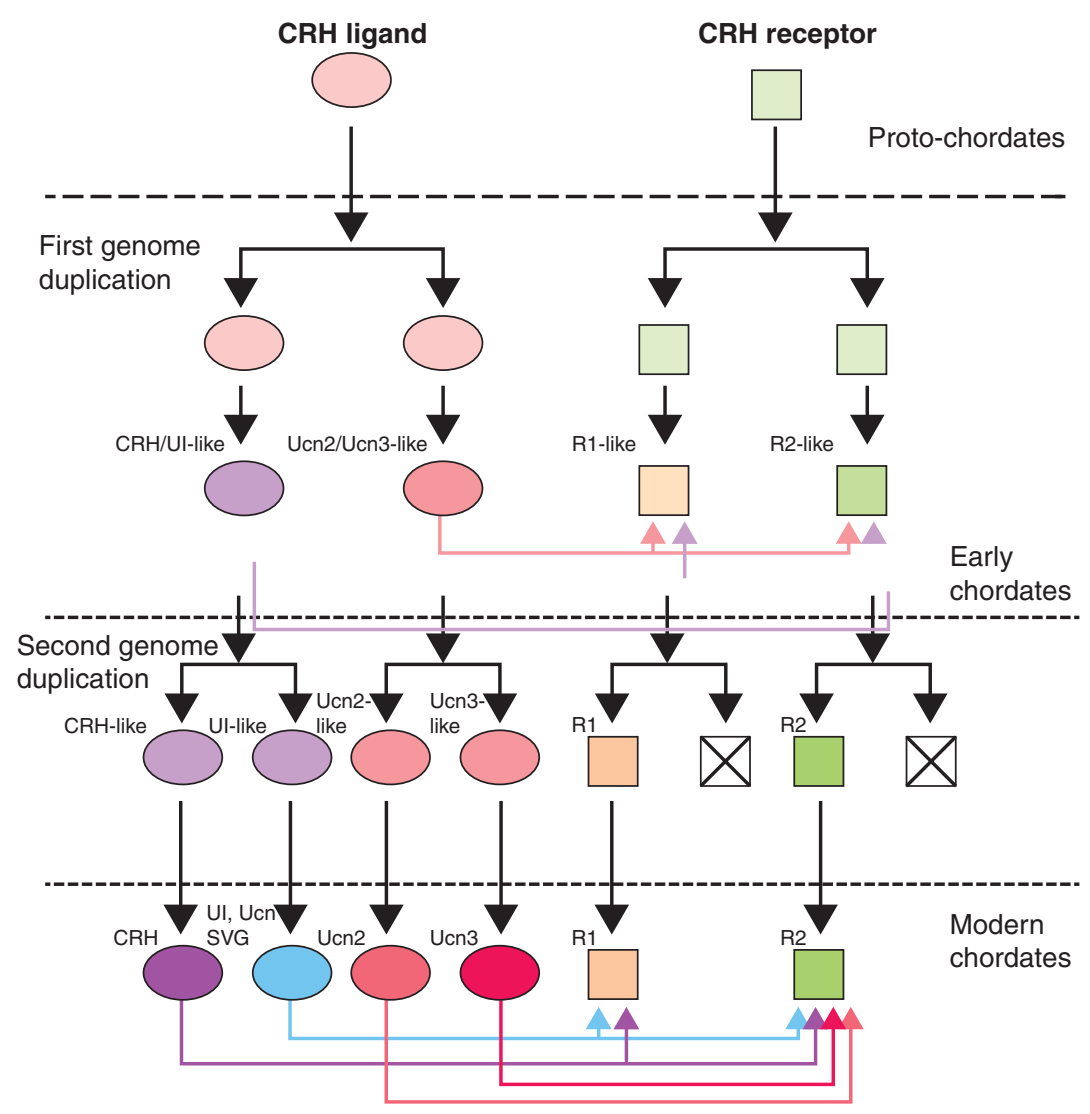

Figure 3

A model for the $\mathrm{CRH}$ peptide and receptor co-evolution in chordates. A single ligand and receptor gene present in the protochordate genome was inherited by the early chordates. The first round of genome duplication led to the initial expansion of ligand and receptor into two paralogues. Over time, the receptors evolved into early R1 and R2 forms, whereas the two peptide genes evolved into either $\mathrm{CRH} / \mathrm{UI}$-like or Ucn2/Ucn3-like forms. The next genome duplication created the divergence of $\mathrm{CRH}$-like peptides

primarily and reproduction secondarily. Thus, the formation of the CRH-like peptides in ancestral metazoans may have been selected and conserved through evolution because they acted to regulate the utilisation of cellular and organismal energy acquisition and production for defence against environmental stressors. This has come to be known as the organismal stress response that acts to protect the organism from external and internal environmental challenges.

\section{Discovery, structure and evolution of CRH receptors}

Although the original discovery of an active corticotrophin-releasing factor necessitated that at least one type of receptor was present, it was not until the first comparative pharmacological studies of ovine CRH, frog into $\mathrm{CRH}$ and $\mathrm{UI} / \mathrm{U} \mathrm{cn} / \mathrm{SVG}$ and Ucn2 and Ucn3 forms, whereas the receptors diverged into R1 and R2 forms. We postulate that the redundant R1 and R2 paralogues were subsequently lost and, therefore, only two CRH receptors were retained by modern chordates. $\mathrm{CRH}$, corticotrophin-releasing hormone; UI, urotensin I; Ucn, urocortin. The black lines and arrows indicate the evolutionary direction and selection. Coloured arrows matching the ligand indicate the affinity for the receptors.

SVG and fish UI were carried out that evidence of additional classes of binding sites became known. In 1985, Lederis et al. suggested that, based on the comparative affinities of CRH, UI and SVG in a number of different tissue types, the mammalian vascular receptors were different from those on the mammalian pituitary corticotrophs and further postulated that the mammalian vascular and fish pituitary receptors may be similar, whereas the mammalian pituitary receptors are different.

Attempts to characterise the CRH receptor began shortly after the discovery of ovine CRH (Vale et al. 1981). High-affinity CRH-binding sites were subsequently established in rat and human pituitary glands and brains (Wynn et al. 1983, DeSouza et al. 1984, 1985, 1986), as well as in the corticotroph cell line AtT20 (Rosendale et al. 1987). Moreover, this receptor was shown to be associated with a cAMP-dependent signal transduction system

Published by Bioscientifica Ltd 
(Labrie et al. 1982, Aguilera et al. 1983, Bilezikjian \& Vale 1983) likely via a G-protein (Perrin et al. 1986; Fig. 2). Attempts to purify the receptor showed a molecular weight of 40-45 kDa (Nishimura et al. 1987, Grigoriadis \& DeSouza 1989). However, many attempts to solubilise and purify the receptor for amino acid sequencing analyses were ultimately unsuccessful. A soluble highaffinity $37-\mathrm{kDa}$ CRH-binding protein was, however, isolated from human plasma and partially characterised (Behan et al. 1989) and cloned shortly after (Potter et al. 1991). However, the structure of this protein was unique and did not possess any attributes, suggesting that it may be related to the sought-after membrane-bound receptor.

The first CRH receptor (CRH1) was reported by Chen et al. (1993) after preparing an expression library from a human corticotrophic tumour. This landmark publication defined the archetype of the $\mathrm{CRH}$ receptor. The cloned cDNAs encoded a receptor of 415 residues and a second splice variant with a 29-residue extension. Further cloning studies indicated that the CRH1 receptor showed a considerable structural variability and varied from 415 to over 440 residues (Arai et al. 2001, Pohl et al. 2001, Huising et al. 2004, Hauger et al. 2006). For example, the human CRH1 gene possesses 14 exons spanning $20 \mathrm{~kb}$ (Sakai et al. 1998), whereas the rat gene possesses only 13 exons (Tsai-Morris et al. 1996). In the Japanese pufferfish (Fugu rubripes), this receptor consists of 14 exons encompassing $27 \mathrm{~kb}$ over the genomic sequence (Cardoso et al. 2003).

The CRH1 receptor was established to be a member of the guanine protein GPCRs family (Chen et al. 1993), one of the largest and most studied families of receptors. Their signature characteristic is the presence of a highly conserved seven-transmembrane domain (Cardoso et al. 2006). They bind to a variety of ligands including protons, odorants, biogenic amines, peptides and glycoproteins resulting in a variety of G-protein-mediated effects (Ulloa-Aguirre et al. 1999, Fredriksson et al. 2003). The CRH1 and subsequent paralogues (see below) were established to belong to the family B GPCRs and share the common characteristic of a long N-terminal domain and a highly glycosylated external domain (Attwood \& Findlay 1994, Harmer 2001, Fredriksson et al. 2003). Ligands for $\mathrm{B}$ family receptors also include vasoactive intestinal peptide, calcitonin, parathyroid hormone, secretin, growth hormone-releasing hormone, glucagon and pituitary adenylate cyclase-activating peptide (Fredriksson et al. 2003). This family of receptors is particularly important for the regulation of ion and nutrient transport as well as playing a role with various elements of the stress response (Harmer 2001, Fredriksson et al. 2003, Harmer 2001).

The origins of this group of receptors can be traced to a period before the bifurcation of deuterostomes and protostomes, over 500 million years ago. However, as this GPCR family is particularly well established in chordates (deuterostomes; Fredriksson et al. 2003) and arthropods (protostomes; Kwon et al. 2012, Veenstra et al. 2012, Li et al. 2013), its earliest origins may be much earlier. The first prototypes of this receptor family may have begun during the beginning of bilateral animal evolution, as there is no clear evidence of this receptor family in basal metazoans such as Placozoa, Porifera, Ctenophora or Cnidaria. The early evolution of the family B GPCRs and, therefore, the earliest CRH receptors agrees with the postulated time of origin for CRH-like peptides (Lovejoy \& Balment 1999, Lovejoy \& Jahan 2006, Lovejoy $\&$ de Lannoy 2013). Of the family B receptors, the CRH receptors show the closest structural similarity to the calcitonin (amylin, guanylin and calcitonin gene-related peptide) family of receptors (Fredriksson et al. 2003). This relationship among receptors is also reflected by the high sequence similarity of the insect calcitonin-related peptide, DH31, to Ucn2 and Ucn3 and also the tunicate CRF-like peptide (Coast et al. 2001, Lovejoy \& Jahan 2006, Lovejoy \& Barsyte-Lovejoy 2010, Kwon et al. 2012). Moreover, the DH31 peptide binds and activates a calcitonin-like receptor in insects where it plays a diuresis role (Furuya et al. 2000, Brugge et al. 2008, Christie et al. 2010, Zandawala et al. 2011, Kwon et al. 2012, Zandawala 2012).

The CRHR1A receptor is the dominant subtype that is widely expressed in the mammalian brain and a number of peripheral tissues (Hillhouse \& Grammatopoulos 2006) and is associated directly with the organismal coordination of the HPA/I-associated stress response. Given the evolutionary selection and conservation of this mechanism, it is perhaps not surprising that a number of alternatively spliced tissue-specific forms that show modified signal transduction ability have also been identified, which act to modify the elements of the stress response (Chen et al. 2005, Hauger et al. 2006). A complete understanding of the combined role of these receptor subtypes is not achieved, but it was found that they may act in part to provide a 'fine-tuning' of the CRH1-mediated stress response. For example, the CRHR1D variant, which shows impaired cellular signalling ability, may act as a decoy receptor that competes with CRHR1A to modify the response due to incoming $\mathrm{CRH}$ - or Ucn-mediated

Published by Bioscientifica Ltd 
signals (Hillhouse \& Grammatopoulos 2006), although this has yet to be conclusively established.

The CRH2 receptor was reported shortly after the discovery of the CRH1 receptor. The identification and structural characterisation of the $\mathrm{CRH} 2$ receptor were reported in mouse (Kishimoto et al. 1995, Perrin et al. 1995, Stenzel et al. 1995), rat (Lovenberg et al. 1995) and human (Liaw et al. 1996). The designation of CRH1 and CRH2 receptors by Lovenberg et al. (1995) was ultimately adopted as the international nomenclature of the CRH receptors. There are three recognised splice variants (CRH2a, CRH2b and CRH2c) and two truncation variants of the CRH2 receptor found in mammals, but only the CRH2a variant has been clearly identified in nonmammals (Arai et al. 2001, Hauger et al. 2006, Hillhouse $\&$ Grammatopoulos 2006). The receptors can be distinguished on the basis of the amino acid sequence of their amino-terminal domain. In addition, the CRH2a receptor form was initially reported to be processed as a soluble binding protein that consists of the first extracellular domain (Chen et al. 2005); however, later studies indicated that this truncated mRNA could not be secreted due to an ineffective signal peptide (Evans \& Seasholtz 2009). The CRH 2 gene consists of 15 exons encompassing about $50 \mathrm{~kb}$ in the genome. The first four exons encode the different $5^{\prime}$ ends of the receptor and the remaining exons encode the remaining parts of the receptor (Pohl et al. 2001, Catalano et al. 2003, Hauger et al. 2006).

Generally, orthologues of both CRH1 and CRH2 receptors are about $80 \%$ or more identical to each other at the amino acid level, whereas there is about $70 \%$ residue sequence identity among paralogues. However, there is only about 30\% identity of the CRH receptors with other members of the family B GPCRs. The greatest level of sequence identity occurs among the intracellular and transmembrane regions, whereas the extracellular regions are more variable. The third intracellular loop, which possesses the G-protein-interacting site, is the most highly conserved one, with the identity approaching $100 \%$ in mammalian orthologues (Hauger et al. 2006). For example, the rhesus monkey (Macaca mulatta) possesses $99.5 \%$ identity at the amino acid level with humans, and as expected, has a pharmacological profile similar to the human CRH1 receptor (Oshida et al. 2004).

Other types of CRH-binding receptors and proteins have been identified. A third CRH receptor (CRH3) was found in the catfish, Ameiurus nebulosus (Arai et al. 2001). However, because of the close structural and pharmacological similarity between the catfish CRH1 and CRH3 receptors, it was likely that the third receptor is the result of the extra genome duplication that occurs in a number of teleost lineages (Wolfe 2001, Mungpakdee et al. 2008, Mulley et al. 2009), including, for example, the white sucker (Morley et al. 1991), goldfish and rainbow trout (Doyon et al. 2003), where two Crh peptides are present. Interestingly, two CRH forms have been identified in the chondrichthyan, C. milii, although the identification of the CRH receptors has not been established (Nock et al. 2011). Irrespective of this, the selection pressure in other taxonomic groups of fish led to the retention of this extra receptor, although the reasons for this are not entirely understood.

The CRH-binding protein, which is structurally distinct from the $\mathrm{CRH}$ receptors, is a $37 \mathrm{kDa} N$-linked glycoprotein that binds to both CRH and Ucn and its orthologues (Valverde et al. 2001, Sutton et al. 1995), although no clear paralogues of this protein have been identified (Behan et al. 1989, Potter et al. 1991, Huising et al. 2004, Huising \& Flik 2005). The role of the binding protein is unclear. Comparative binding studies indicate that it possessed a greater affinity for UI and SVG (Sutton et al. 1995) and later Ucn (Vaughan et al. 1995). Orthologues of this protein are well established in the insect lineages. Such conservation indicates that the binding protein evolved early in the evolution of $\mathrm{CRH} / \mathrm{DH}$ ligand-receptor systems and has become an integral part of the $\mathrm{CRH}$ and $\mathrm{DH}$ physiology.

\section{Ligand specificity and signal transduction mechanisms}

The CRH1 receptor has the highest affinity for CRH as well as Ucn and its orthologues (UI and SVG) and virtually no affinity for Ucn2 and Ucn3 (Figs 2 and 3). Despite initial postulations that Ucn (and therefore UI) was the cognate ligand for the CRH2 receptor, neuroanatomical studies did not support this supposition (Bittencourt et al. 1999, Bittencourt \& Sawchenko 2000; Fig. 2). In fact, the CRH2 receptor is much more promiscuous than the CRH1 receptor and binds to all vertebrate paralogues, as well as a number of synthetic CRH peptide variants (Tellam et al. 2002, Hauger et al. 2006). The ligand specificity of the receptor reflects its evolution. Ucn2 and Ucn3 are the products of a direct gene (genomic) duplication, whereas CRH and Ucn (UI and SVG) are the result of a separate direct gene duplication. Thus, their functional distinctiveness, with respect to their receptor affinities, is consistent with this evolution (Boorse et al. 2005, Lovejoy $\&$ Jahan 2006, Lovejoy \& De Lannoy 2013).

Published by Bioscientifica Ltd 
The pharmacological activities among the four CRHlike ligands and their two receptors provide insight into the evolutionary selection pressure on the CRH receptorligand co-evolution. Although much data are missing and it is not known when the CRH receptors were duplicated, with respect to the vertebrate genome expansion event (2R) concerned, it is possible to provide a plausible model for CRH ligand and receptor co-evolution. However, given the promiscuous association of the $\mathrm{R} 2$ form with all four CRH-related ligands, we postulate that CRHR1 and CRHR2 resulted in the first round of genome duplications. In the second round of genome duplications, the new paralogous receptor genes were subsequently lost (Fig. 3).

A large number of studies have indicated not only that there may be a ligand- and receptor-mediated role to signal transduction but also that tissues may impart a third level of specificity (Grammatopoulos et al. 2000). The C-termini of the CRH family of ligands bind to the extracellular binding pocket of both receptors, whereas their N-termini interact with the other extracellular loops to activate the intracellular signal cascade (Grace et al. 2004, Hoare et al. 2004). Pharmacological studies of the various $\mathrm{CRH}$ homologues established that the $\mathrm{C}$-terminus of the peptide binds to the extracellular binding region of the CRF receptors, whereas its N-terminus stimulates the intracellular signalling cascade via interaction with other regions in the receptor (Perrin \& Vale 2002). The primary signal transduction system for all CRH receptors characterised to date occurs via the coupling of G-stimulatory (Gs) proteins leading to activation of the adenylate cyclase-protein kinase A (PKA) pathway (Chen et al. 1993, Olianas et al. 1995, Hauger et al. 2006) (Fig. 2). However, there is considerable evidence that the CRH receptors can also couple with Gq-proteins and other G-proteins to stimulate inositol trisphosphates ( $\left.\mathrm{IP}_{3}\right)$ - and $\mathrm{Ca}^{2+}$-mediated signal transduction pathways (Hauger et al. 2006, Gutknecht et al. 2010). Moreover, further studies indicate that CRH receptors are coupled to and activate at least five different G-proteins (Gs, Gi, Gq/11, Go and Gz; Grammatopoulos et al. 2001). Some of these effects may be ligand dependent. For example, in cultured human pregnant myometrial cells, Ucn, but not CRH, induces MAPK phosphorylation and activation, suggesting that these two peptides have distinct actions and biological roles in the human myometrium. In stably expressed HEK293 and CHO cells, the CRHR1A and CRHR2B, but not the CRHR1B, CRHR1C and CRHR1D, receptor subtypes mediate Ucn-induced MAPK activation. Activation of $\mathrm{Gq}$, with subsequent production of $\mathrm{IP}_{3}$ and PKC activation, correlated with MAPK phosphorylation.
In these studies, Ucn was ten times more potent than CRH. Other pathways may also be activated. For example, the ERK1/2-mediated pathway is also activated in a number of in vitro systems (Brar et al. 2004, Hauger et al. 2006).

\section{Expression of $\mathrm{CRH}$ receptors}

Consistent with the early evolution of CRH receptors in the Metazoa are the findings of CRH receptors in diverse tissues that mediate a spectrum of physiological effects. Generally, CRH receptors are associated with the homoeostatic actions on cells and organisms with respect to energy metabolism and the associated diuretic requirements in response to stressful challenges (Chen et al. 2003, Lovejoy 2012, Janssen \& Kozicz 2013, Lovejoy \& De Lannoy 2013). Fundamentally, the CRH peptide and receptor system is associated with sympathetic arousal in vertebrates. Systems associated with parasympathetic activation (e.g. growth, feeding and digestion) may be expected to be inhibited by CRH activation, whereas sympathetic arousal systems associated with adrenal/ interrenal and cardiovascular activity, for example, are more likely to be activated by $\mathrm{CRH}$-associated peptides.

Both receptors are expressed in a number of tissues throughout the organism and appear to vary with respect to species and taxa, although information is far from complete. Generally, however, the CRH1 receptor is predominantly found in the CNS, whereas the CRH2 receptor, although highly expressed in the CNS, is found to a greater degree, relative to the CRH1 receptor, in peripheral tissues. If the earliest function of the CRH-DH system is considered, assuming that its initial function was to regulate stressful stimuli associated with diuresis and feeding, then the expression of the CRH receptors would be expected to be found in the tissues of more complex organs associated with these functions.

In vertebrates, the CRH receptors are expressed early in development. The CRH1 and CRH2 receptors display distinct patterns of development in foetal brains whose expression patterns vary during foetal and postnatal life until becoming more stable in adulthood (Avishai-Eliner et al. 1996, Eghbal-Ahmadi et al. 1998). The hippocampus, hypothalamus and cerebellum have been particularly well studied. For example, in rats, CRH2 is expressed in the ventromedial hypothalamus $(\mathrm{VMH})$ on foetal day 16 , before the detection of CRH itself in the paraventricular nucleus, where it may act to regulate the actions of CRH and their paralogues on target neurons (Eghbal-Ahmadi et al. 1998). Moreover, in the developing cerebellum, CRH2a is involved in the survival and differentiation of

Published by Bioscientifica Ltd 
Purkinje cells and GABAergic neurons, whereas in the adult, CRH2a may act to modulate glia associated with the regulation of cells (Lee et al. 2007). Similar findings in the opossum cerebellum have been reported by Madtes \& King (1996). Unfortunately, there are few comparative studies on non-mammals. In the zebrafish, early-stage larvae show an expression of both Crh receptors and the binding proteins, Crh and Ui (Alderman \& Bernier 2009). In amphibians, $\mathrm{CRH}$, and their cognate receptors, plays a major role in metamorphosis (Denver 1997) as well as being associated with pituitary thyrotrophin release (Manzon \& Denver 2004).

In adult mammals (notably rodents), a number of studies in the brain have indicated that the CRH1 receptor is highly expressed in the cortex, hippocampus, amygdala, olfactory bulb, lateral septum, thalamus, raphe nucleus, pituitary gland and spinal cord (Van Pett et al. 2000; Fig. 4). Among neurotransmitter systems associated with the CNS, the CRH1 receptor is present in glutamatergic neurons of cortex and hippocampus, GABAergic cells in the reticular thalamic nucleus, globus pallidus and septum, dopaminergic neurons of the substantia nigra pars compacta and ventral tegmental area and in 5-HT neurons of the dorsal and medial raphe nuclei (Refojo et al. 2011).

The CRH1 receptor is also found in a number of peripheral tissues, for example, in the female reproductive tract (Nappi \& Rivest 1995, Kiapekou et al. 2011), skin (Slominiski et al. 1995), adrenal gland (Willenberg et al. 2006, Squillacioti et al. 2011) and gastrointestinal (GI) tract (Chatzaki et al. 2004). Among teleost fish, the Crh1

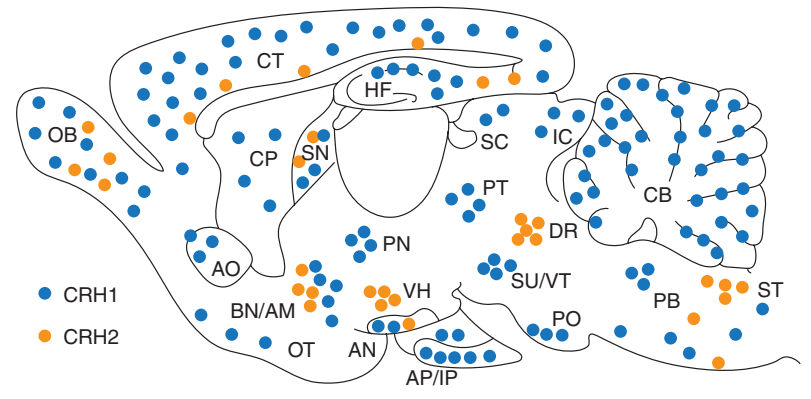

\section{Figure 4}

Major regions of $\mathrm{CRH} 1$ and $\mathrm{CRH} 2$ expression in rat brain. $\mathrm{AM}$, amygdala; AN, arcuate nucleus; $A O$, accessory olfactory bulb; $A P$, anterior pituitary gland; $\mathrm{BN}$, bed nucleus; $\mathrm{CB}$, cerebellum; $\mathrm{CP}$, caudate putamen; $\mathrm{CT}$, cortex; $\mathrm{DR}$, dorsal raphe nucleus; $\mathrm{HF}$, hippocampal formation; IC, inferior colliculus; $I P$, intermediate lobe of the pituitary gland; $O B$, olfactory bulb; $\mathrm{PB}$, parabrachial nucleus; PN, paraventricular nucleus; PO, pontine nuclei; SC, superior colliculus; SN, septal nucleus; ST, nucleus of the solitary tract; SU, substantia nigra; VMH, ventromedial hypothalamus; VT, ventral tegmental area. Printed in Great Britain receptor is expressed in a number of tissues. In the Japanese pufferfish, it is found in brain, liver, heart, gonads, and to a lesser extent, in kidney, gut and gills (Cardoso et al. 2003). In the common carp (Cyprinus carpio), this receptor has been found in integument and gills (Mazon et al. 2006).

Overall, the CRH2 receptor shows a more limited expression relative to the CRH1 receptor based on rodent studies (Lovenberg et al. 1995, Perrin et al. 1995, Van Pett et al. 2000). In comparison to the CRH1 receptor, it is poorly expressed in the cortex and is generally predominately expressed in subcortical regions such as the VMH, dorsal raphe nuclei of the midbrain, nucleus of the solitary tract in the hindbrain and various hindbrain nuclei (Bittencourt et al. 1999; Fig. 4). It is also found in a number of regions that also express the CRH1 receptor, such as the septal nuclei. Although CRH1 is predominant in the medial septal nuclei, $\mathrm{CRH} 2$ is more prevalent in the lateral regions of this nucleus. These findings led, in part, to the original supposition that Ucns (UI and SVG) were the cognate ligand of the CRH2 receptor (Vaughan et al. 1995). However, later studies (Bittencourt et al. 1999) indicated that many of the CRH2-expressing regions of the brain did not receive input from Ucn-containing fibres. In the peripheral regions, the $\mathrm{CRH} 2$ receptor has been localised to heart (Kishimoto et al. 1995, Lovenberg et al. 1995, Perrin et al. 1995, Stenzel et al. 1995), lung (Lovenberg et al. 1995), GI tract (Perrin et al. 1995, Chatzaki et al. 2004), skeletal muscle (Kishimoto et al. 1995), male reproductive system (Perrin et al. 1995) and adrenal gland (Muller et al. 2001).

\section{Evolution of $\mathrm{CRH}$ receptors}

Currently, the literature consistently shows that a single CRH-like receptor (DH) is present in non-chordates (protochordates and arthropods), whereas two receptors (CRH1 and CRH2) are the norm for chordates. In nonchordates, a single CRH-like ligand is associated with its putative cognate $\mathrm{CRH}$-like receptor. There are some lineage-specific exceptions. For example, in Ciona, there are two CRH receptors in the genome, but one ligand (Sherwood et al. 2006, Lovejoy \& Barsyte-Lovejoy 2010), although the two Ciona CRH-like receptors appear to be gene duplications confined to the tunicates (Sherwood et al. 2006). However, in chordates, there are typically four CRH-related ligands, yet only two receptor paralogues. Although the number of ligands is in agreement with the $2 \mathrm{R}$ hypothesis, this is not the case with the receptors. A single receptor gene, inherited by the basal chordates,

Published by Bioscientifica Ltd 
should have diverged into two receptors after the first genomic duplication and then four after the second genomic duplication. No species have been found with more than two CRH receptors, with the exception of a catfish which, although does possess a third receptor, appears to be the result of a lineage-specific genome expansion event. As a result, we conducted a detailed in silico analysis of the gene and genomic databases using a BLAST search (Fig. 5).

Thus, utilising this methodology, we could only discern a single receptor system present in non-chordates and two receptors found in chordates consistent with the literature. CRH1 and CRH2 receptors in chordates cluster as distinct clades along the expected phylogenetic lines. Both receptors form a sister lineage to the DH receptors found in invertebrates. However, the presence of only two receptor systems in chordates does not seem to be consistent with the 2R hypothesis (Amores et al. 1998, Mungpakdee et al. 2008, Mulley et al. 2009). Theoretically, four receptor genes should have occurred as a result of the two genomic expansion events (see earlier discussion). One interpretation is that the other set of receptors, resulting from the second gene duplication, were redundant and lost through chordate evolution. This should manifest as the appearance of pseudogenes, yet currently none have been detected. This suggests that the expected paralogues resulting from the second genome expansion event may have been lost early in chordate evolution (Figs 3 and 6). Two CRH-like receptors have been identified in Ciona although they are more similar to each other than either is to the vertebrate CRH1 and CRH2 receptors (Campbell et al. 2004, Sherwood et al. 2006), suggesting that the two genes are likely the result of a gene duplication event in the urochordates and are consistent with the notion of chordates inheriting only a single $\mathrm{CRH}$ receptor gene. Thus, given this scenario, we suggest that before the bifurcation of deuterostomes and protostomes, only a single CRH-like ligand, receptor and binding protein were present, which acted as an integrated functional unit to develop into the complex CRH system present in chordates (Fig. 6).

\section{Functions of the $\mathrm{CRH}$ receptors}

Once a new gene or protein becomes selected for a function that increases the fitness of an organism, then it is less likely to change in subsequent generations. The pre-vertebrate evolution of the $\mathrm{CRH}$ receptors that occurred before the bifurcation and subsequent development of more complex deuterostome and protostome lineages meant that this receptor-ligand system became well ensconced into many physiological circuits spanning diverse tissues (see earlier section). Moreover, its utilisation as an endocrine/neuroendocrine system regulating the control of energy metabolism, as a response to homoeostatic stressors led to the regulation of tissue and organ physiologies that were ultimately affected by these stressors. In continuation of this trend, a major physiological development in the CRH system in chordates was the formation of a functional HPA system.

The CRH peptide became associated with the regulation of the HPA/I axis, and because it was now controlled by a much greater physiological constraint, there was less variation in its primary structure. This conservation of function is reflected by the pharmacology of the CRH1 receptor that shows greater selectivity for its ligands. Thus, in this respect, the CRH1 receptor is more specialised than the $\mathrm{CRH} 2$ paralogue. The formation of the $\mathrm{HPA} / \mathrm{I}$ axis acted to combine the neural actions of the CRH peptide with the glucocorticoid-synthesising tissues of the periphery, thereby linking a comparatively large and mobility-constrained neuropeptide (i.e. CRH) with a small lipophilic hormone (e.g. cortisol/corticosterone) that could pass through all membranes with ease, and placing the entire organism under the control of a single neuropeptide. In addition, as CRH were under the control of sensory and associative inputs, its regulation allowed the HPA/I axis to act as a stress-perceiving and integrating unit, thereby allowing the anticipation of a future stressor.

The earliest functions of the proto-CRH receptors appear to be associated with osmoregulation, which may be considered the most basic and ubiquitous environmental stressors. Indeed, there were several 100 million years of metazoan evolution before animals were capable of surviving in terrestrial environments. Similar to CRH, UI (Ucn and SV) binds both receptors with physiologically equivalent affinity. In vertebrates, UI became specialised for its role in the urophysis in an analogous manner that CRH became associated with the HPA/I axis. The urophysis or caudal neurosecretory system is analogous to the neurohypophysis in that it is a neurohaemal organ where the neurosecretory cells release their constituents into the fenestrated capillaries of the vascular system. The caudal neurosecretory system is found in all fish but has been reduced in the sarcopterygian line and is lost entirely in the tetrapods. Thus, this organ system likely evolved in order to adapt to the osmoregulatory stress of rapidly changing ambient conditions, such as salinity, that occur in the water column. The urophyseal UIs have been implicated in ion and fluid equilibrium (Lederis et al. 1985)

Published by Bioscientifica Ltd 
and cardiovascular activity (Platzack et al. 1998, Le Mevel et al. 2006), and they can participate in interrenal glucocorticoid release (Arnold-Reed \& Balment 1994, Kelsall \& Balment 1998), all of which are necessary for the adaptability of fish.

While osmoregulatory control may be considered as the primary aspect of a stress response, energy regulation in the form of nutrient acquisition, digestion and utilisation may be considered as the second most important physiology to be protected from a stressor. The role of the CRH ligands and receptors has been studied in detail by many authors (Spina et al. 1996, Audsley et al. 1997, Zorrilla et al. 2003, Kuperman \& Chen 2008). Recently, studies have suggested that while CRH1 may retain much of its osmoregulatory role, the $\mathrm{CRH} 2$ receptor, through the actions of its ligands, Ucn2 and Ucn3, may be more associated with energy regulation including metabolic rate, appetite and feeding behaviours (Kuperman \& Chen 2008). For example, the VMH is responsive to changes in circulating glucose and therefore acts, in part, to integrate organismal glucose intake and stores with the needs of the organism. CRH1 activation stimulates the organismal response to low plasma glucose, whereas the $\mathrm{CRH} 2$ receptor inhibits this response (Makino et al. 1999, Cheng et al. 2007).

Mammalian models have been the most studied with respect to CRH receptors and their activity in GI function. A large number of studies on humans, rodents, cats and dogs have demonstrated that diverse stressful stimuli induce a variety of actions on the GI tract that typically include delayed gastric emptying and colonic motor activity (Tache et al. 2001, Tache \& Bonaz 2007). Although activation of the autonomic nervous system is responsible for regulation of gastric physiology, $\mathrm{CRH}$ receptors in the

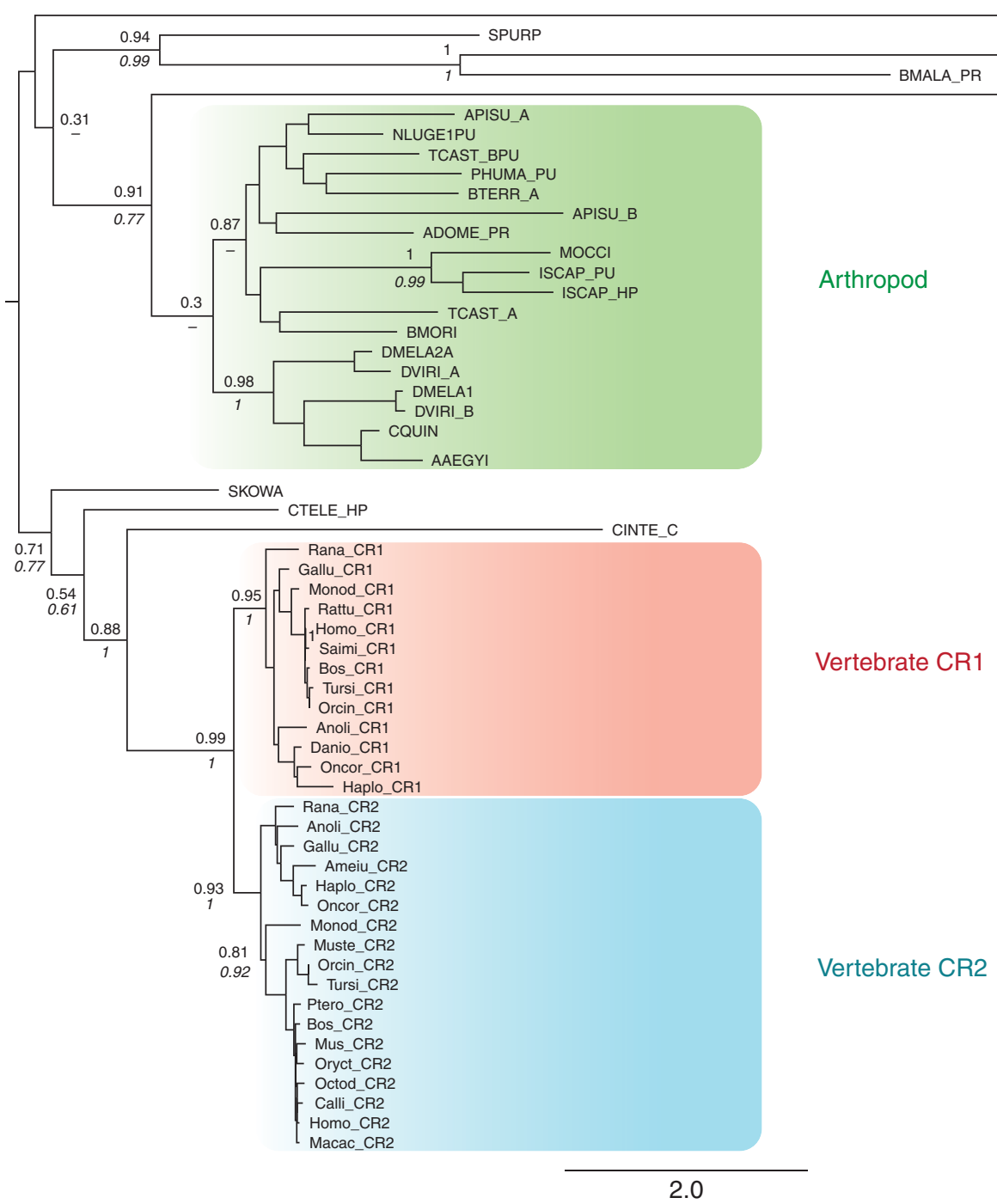


GI tract play a major role in the acute and chronic actions of stress (Williams et al. 1987, Gue et al. 1991, Tache et al. 2001). The vagus nerve is the main pathway that mediates the delayed gastric emptying and inhibition of gastric motility by CRH and Ucn in rats and dogs. Psychological stress and central administration of CRH and Ucn inhibit small intestine transit and motility via an HPA-independent vagal nerve-associated pathway suggesting a CRH1 receptor mechanism (Kellow et al. 1992, Tache \& Bonaz 2007). Ucn2, on the other hand, utilises a CRH2dependent receptor mechanism that mediates a sympathetic adrenergic receptor system to delay gastric emptying (Martinez et al. 2004, Czimmer et al. 2006).

The HPA and hypothalamus-pituitary-thyroid (HPT) axes are closely coupled and the CRH may act as a thyrotrophin-releasing factor in some species (fish and amphibians; Denver 1997). In chordates, thyroid physiology is required for the maintenance of metabolic rate and regulation against metabolic challenges associated with temperature extremes and general energetic demands. In frogs, CRH2-selective ligands stimulate thyrotrophin release from the pituitary, an effect that is blocked by CRH2-specific antagonists, but not CRH1specific antagonists (De Groef et al. 2006, Okada et al. 2007). In the thyroid gland, CRH 1 and CRH 2 receptors are differentially expressed where CRH2 is localised to the
C-cells and CRH1 in blood vessels (Squillacioti et al. 2012). Moreover, mice lacking the $\mathrm{CRH} 2$ receptor show impaired responses to cold stressors (Bale et al. 2003), a function that is generally attributed to the HPT axis.

Assuming that the organism's osmoregulatory and energetic demands are met and it can survive various stressful challenges, arguably the next essential physiology is associated with reproduction. The actions of HPA axis and CRH peptides in the regulation of reproduction have been well documented over a large number of studies in the last 30 years (see Tellam et al. (2000), Chand \& Lovejoy (2011) and Lovejoy \& Barsyte (2011) for detailed discussions). However, the roles of the receptors have become apparent only recently. For example, both the CRH1 and CRH2 receptors modulate aspects of gonadotropin-releasing hormone $(\mathrm{GnRH})$ synthesis, pulsativity and release into the portal blood vessels (Tellam et al. 2000, Li et al. 2010), which may not only affect GnRH and reproduction in the adult, but also regulate the timing of puberty (Kinsey-Jones et al. 2010). However, these actions involve both a direct effect of CRH peptides on $\mathrm{GnRH}$ neurons and the many indirect regulatory systems associated with GnRH release. The CRH1 receptor has been implicated in a number of reproductive processes at the peripheral level. In mouse preantral follicles and oocyte development, CRH inhibit growth and

\section{Figure 5}

Maximum-likelihood phylogeny of CRF-like proteins. CRH-like protein sequences were obtained via BLAST searches of the NCBI sequence database, aligned using ClustalW (Thompson et al. 1994, Larkin et al. 2007) and trimmed by hand to eliminate regions of uncertain alignment. The trimmed data set was then subjected to phylogenetic analyses using the maximum-likelihood and Bayesian methods (Guindon \& Gascuel 2003, Ronquist \& Huelsenbeck 2003, Guindon et al. 2010). The maximumlikelihood phylogenetic methods were implemented in the program PHYML 3.0 (Guindon \& Gascuel 2003, Guindon et al. 2005), using the LG amino acid replacement matrix (Le \& Gascuel 2008). For the likelihood analyses, node support was assessed using an approximate likelihood-ratio test (aLRT, Anisimova \& Gascuel (2006)). Bayesian inference was performed in MrBayes 3.1.2, using a model that allows for jumping among fixed amino acid substitution rate matrices (Ronquist \& Huelsenbeck 2003), with all of the protein sequence data in a single partition. Two Markov chain Monte Carlo runs were performed, with four chains each (three heated and one cold) for 1 million generations. Convergence was assessed using standard methods, including the average s.D. of split frequencies and the potential scale reduction factor (PSRF, Gelman \& Rubin (1992)). The first $25 \%$ of trees sampled were discarded as burn-in, and the remaining trees were taken as representative of the posterior probability distribution (Fig. 4). Node is support indicated by likelihood aLRT values and Bayesian posterior probabilities (italics). $\mathrm{CRH} 1$ and $\mathrm{CRH} 2$ receptors cluster as discrete groups and represent together a sister lineage of the insect $\mathrm{DH}$ receptors. Species abbreviation, species name and accession name are indicated: ADOME: Acheta domesticus, Q16983.1; AAEGYI: Aedes aegypti, ABX57919.1;
Ameiu: Ameiurus nebulosus, AAK01069; Anoli: Anolis carolinensis, XP0032211923; APISU A: Acyrthosiphon pisum, XP003244979.1; APISU B: Acyrthosiphon pisum, XP001944842.2; BMALA: Brugia malayi, XP 001899608.1; BMORI: Bombyx mori, XP004933474.1; Bos R1, R2: Bos taurus, NP776712 and NP001179474; BTERR: Bombus terrestris, XP003394723.1; Calli: Callithrix jacchus, XP002748148; CGIGA: Crassostrea gigas, EKC3340.1; CINTE: Ciona intestinalis, XP002123381.1; CQUIN: Culex quinquefasciatus, DAA06284.1; CSINE: Clonorchis sinensis, GAA51272.1; Danio: Danio rerio, XP696346; DMELA1, A2: Drosophila melanogaster, NP610960.1 and NP725175.3; DVIRIA, B: Drosophila virilis, XP002059297.1 and XP002050193.1; Gallu RI, R2: Gallus gallus, NP989652 and NP989785; Haplo: Haplochromis burtoni, ACV53954; ISCASP_PU,_HP: Ixodes scapularis, XP002403968.1 and XP002403764.1; HomoR1, R2: Homo sapiens, NP001138618 and ABV59317; Macac: Macaca mulatta, EHH17404; MOCCl: Metaseiulus occidentalis, XP002123381.1; Monod R1, R2: Monodelphis domestica, XP001375959 and XM001373511.2; Mus: Mus musculus, Q60748; Muste: Mustela putorius furo, XP004762632; NLUGE: Nilaparvata lugens, CA625575.2; Octod: Octodon degus, XP00466578; Oncor: Oncorhynchus keta, CAC81754; Orcin R1, R2: Orcinus orca, XP004275734 and XP004269989; PHUMA; Pediculus humanus corporis, XP002424517.1; Ptero: Pteropus alecto, ELK12633; Rana: Rana catesbeiana, BAD36784; Rattu: Rattus norvegicus, NP112261; Salmi: Saimiri boliviensis boliviensis, XP003942463; SKOWA: Saccoglossus kowalevskii, NP001161520.1; SPURP: Strongylocentrotus purpuratus, XP790450.3; TCAST: Tribolium castaneum, NP001167548.1; TSPIR: Trichinella spiralis, XP003376880.1 and Tursi R1, R2: Tursiops truncatus, XP004318934 and XP004314441.

Published by Bioscientifica Ltd 


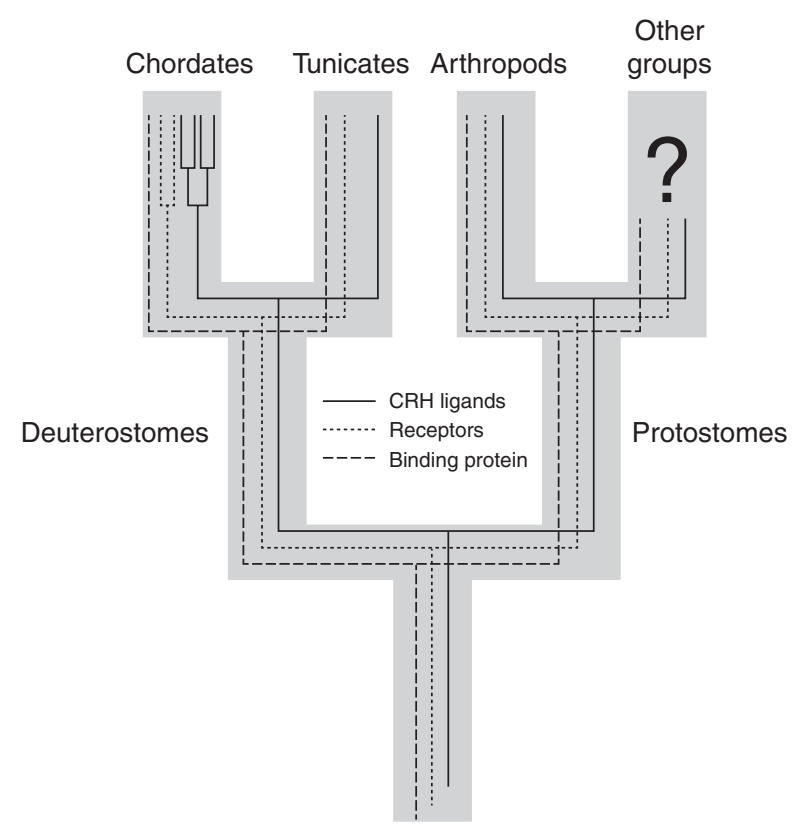

\section{Figure 6}

Evolution and structure-function relationships of CRH receptors. At the origin, only a single ligand, receptor and binding protein were present. Two rounds of gene expansion events in chordates led to the formation of four ligands, two receptors, but only a single binding protein.

development in vitro likely through a CRH1-mediated receptor action (Kiapekou et al. 2011). In monkeys, expression of CRH, UCN and the CRH1 receptor in luteal cells varies as a function of the monkey's menstrual cycle, suggesting that the CRH system and its requisite receptors act, in part, to regulate follicular growth and development (Xu et al. 2007). In the placenta, the glucose transporters, GLUT1 and GLUT3, as well as oestradiol and progesterone biosynthesis are differentially regulated by CRH1 and CRH2 receptors, where they may be involved in local energy requirements of the placenta during different periods of pregnancy (Gao et al. 2012a,b).

The CRH ligand and receptor system has been most intensively studied with respect to both the direct actions of the HPA system and the pathologies associated with its over- or under-activation. At a clinical level, considerable evidence indicates that chronically elevated levels of CRH in the CNS play a significant role in the aetiology of a number of affective and neurological disorders, thus there has been much interest in understanding the regulatory mechanisms of the CRH receptors. This has been reviewed in detail by a number of authors (Dunn \& Berridge 1990, Mitchell 1998, Hauger et al. 2006, Rotzinger et al. 2010, Janssen \& Kozicz 2013). In clinical and mammalian model systems, both receptor systems are implicated in different elements of stress-associated pathologies. However, establishing a clear action for either receptor is confounded by the difficulty in using behavioural models and situations that mimic the human situation. A large number of studies using selective $\mathrm{CRH}$ receptor agonists and antagonists indicated that, generally, a stressor needs to be present in these models to observe a clear effect (see Rotzinger et al. (2010) for a detailed discussion). Recently, the utilisation of receptor knockout studies has revealed considerable insight into the specific actions of $\mathrm{CRH}$ receptors with respect to stress-associated conditions and pathologies. Crh1-specific knockout mice show a reduced response to stressors with slightly elevated ACTH and glucocorticoid levels (Smith et al. 1998), whereas Crh2deficient mice possess a generally normal initiation of the stress response, but show an early termination of the HPAassociated ACTH release and possess an impaired cardiovascular response, although they do not show changes in the stress response using some behavioural models (Coste et al. 2000, 2006).

Despite the difficulties relating the human and mammalian experience to non-mammalian models, there are a number of studies, which suggest, at least with respect to 'emotional' reactivity, that the $\mathrm{CRH}$ receptor system has a similar function. For example, among fish, rainbow trout (Oncorhynchus mykiss) is particularly sensitive to environmental stressors. The high-responder (HR) and low-responder (LR) rainbow trout strains have been particularly useful to understand the role of CRF and HPA/I physiology in fish and nonmammals in general. After confinement, HR trout showed significantly decreased CRH2 in forebrain mRNA when compared with the LR trout, although there was no difference in crh1 transcript levels (Backström et al. 2011). In the crucian carp (Carassius carassius), the CRH1 antagonist, antalarmin, reduced the olfactory-mediated fright reaction leading to a decrease in cortisol levels (Lastein et al. 2008).

\section{Stress response and complementarity of the $\mathrm{CRH}$ receptors in chordates}

The interaction of the CRH1 and CRH2 receptors has become understood from a number of interpretations. Risbrough \& Stein (2006) have summarised two prevailing theories on the role of the $\mathrm{CRH}$ receptors. One such concept posits that the $\mathrm{CRH} 2$ receptors facilitate the recovery of the stress response by inhibiting the initial CRH1-mediated stress response. A second hypothesis suggests that under chronic stress, the $\mathrm{CRH} 2$ receptors could act to facilitate 'depressive-like' behaviour over

Published by Bioscientifica Ltd 
defensive behaviours typically mediated by CRH1 activation (see Hammack et al. (2003), Koob \& Heinrichs (2004) and Coste et al. (2006)). In essence, both of these hypotheses similarly suggest that there are two distinct physiological aspects to the stress response. The initial phase, perhaps coinciding with Selye's (1950) alarm reaction, which as he termed it is a 'call-to-arms' to mediate the homoeostasis challenging actions of the stressor, is mediated by the CRH1 receptor. A second phase, which Selye (1950) termed 'stage of resistance', is the result of secondary physiological mechanisms activated in response to prolonged or chronic stress. Indeed, we had previously argued that as 'depressive'-like behaviours are found in a number of species, this is an evolutionarily conserved response to remove the organism from continued stressful stimuli by sensory withdrawal (Lovejoy \& Barsyte-Lovejoy 2010). In humans, as defined by Selye's (1950), 'stage of exhaustion' may be exemplified as clinical depression and suicide in extreme situations. In non-humans, this behaviour would be manifested by social withdrawal and hiding. Thus, these theories of the actions of the CRH receptors are consistent with our classical understanding of the regulation of the stress response.

However, Janssen \& Kozicz (2013) have recently challenged this view of the respective actions of the receptors, while respecting Selye's (1950) original hypothesis. They have argued that stressful stimuli impinge upon regions of the brain to activate particular neurotransmitter-specific regions (glutamate, GABA, dopamine and 5-HT) depending upon the specific challenge leading to an appropriate stress-associated response that may be mitigated by either CRH1 or CRH2 receptors. For example, citing the study by Refojo et al. (2011), CRH1 knockouts in various transmitter systems in specific regions of the brain, may lead to anxiolytic- or anxiogenic-like behaviours depending upon the behavioural model used for analysis (see above). From an evolutionary point of view, this theory has an advantage. Two rounds of genomic duplication in the chordates have a complex effect on the neurological organisation, and indeed, the physiology of the organism. Widespread genetic expansion events, such as the one expected in an entire genomic duplication, are likely to have a profound effect not only on the requisite genes, but also on the subsequent development of the entire organism. In the brain, this may manifest as novel nuclei, new interneuronal connections and interaction with peripheral organs. As a result, it is not understood as to what type of relationship exists between neuroanatomical development and the formation of novel paralogues of potent neuromodulators such as CRH. Neurotransmitter systems such as glutamate, GABA, dopamine and 5-HT evolved well before peptide modulators such as CRH (see Lovejoy (2005) for discussion), indicating that neuronal networks were well established in the Metazoa before they had the capacity to be modulated by more complex sensory experiences.

\section{Conclusions}

The evolution of the CRH receptors as a functional system integral to diuresis and nutrient regulation in the early Metazoa subsequently led to their widespread expression among the tissues and organs of diverse metazoan species. In chordates, inheritance of this proto-CRH ligandreceptor system was the subject of two rounds of genome duplications, which led to expansion of function. One of these paralogues, the CRH1 receptor, became associated with the HPA/I axis to coordinate the organismal stress response and became specialised for its interaction with CRH and UI and its mammalian orthologue Ucn. The CRH2 receptor remained less specialised to bind and continued to activate all four ligand paralogues (CRH, UI/Ucn, Ucn2 and Ucn3). Both receptors work in tandem to regulate elements of the organismal stress response in vertebrates, but may maintain tissue-specific actions. Coordination of both receptor systems may be regulated by higher neurological systems, for example, the autonomic nervous system.

\section{Declaration of interest}

The authors declare that there is no conflict of interest that could be perceived as prejudicing the impartiality of the review.

\section{Funding}

This work was supported by the Canadian Natural Sciences and Engineering Research Council (grant number 458080, 2010).

\section{References}

Aguilera G, Harwood JP, Wilson JX, Morell J, Brown JH \& Catt KJ 1983 Mechanisms of action of corticotropin-releasing factor and other regulators of corticotropin release in rat pituitary cells. Journal of Biological Chemistry 258 8039-8045.

Alderman SL \& Bernier NJ 2009 Ontogeny of the corticotropin-releasing factor system in zebrafish. General and Comparative Endocrinology 164 61-69. (doi:10.1016/j.ygcen.2009.04.007)

Amores A, Force A, Yan YL, Joly L, Amemiya C, Fritz A, Ho RK, Langeland J, Prince V, Wang YL et al. 1998 Zebrafish Hox clusters and vertebrate 
genome evolution. Science 282 1711-1714. (doi:10.1126/science.282. 5394.1711)

Anisimova M \& Gascuel O 2006 Approximate likelihood-ratio test for branches: a fast, accurate, and powerful alternative. Systematic Biology 55 539-552. (doi:10.1080/10635150600755453)

Arai M, Assil IQ \& Abou-Samra AB 2001 Characterization of three corticotropin-releasing factor receptors in catfish: a novel third receptor is predominantly expressed in pituitary and urophysis. Endocrinology $142446-454$

Arnold-Reed DE \& Balment RJ 1994 Peptide hormones influence interrenal secretion of cortisol in the trout, Oncorhynchus mykiss. General and Comparative Endocrinology 113 87-95.

Avishai-Eliner S, Yi SJ \& Baram TZ 1996 Developmental profile of messenger RNA for the corticotropin-releasing hormone receptor in the rat limbic system. Brain Research. Developmental Brain Research 91 159-163. (doi:10.1016/0165-3806(95)00158-1)

Attwood TK \& Findlay JB 1994 Fingerprinting G protein coupled receptors. Protein Engineering 7 195-203. (doi:10.1093/protein/7.2.195)

Audsley N, Goldsworthy GJ \& Coast GM 1997 Circulating levels of locusta diuretic hormone: the effect of feeding. Peptides 18 59-65. (doi:10.1016/S0196-9781(96)00234-3)

Backström T, Schjolden J, Øverli Ø, Thörnqvist PO \& Winberg S 2011 Stress effects on AVT and CRF systems in two strains of rainbow trout (Oncorhynchus mykiss) divergent in stress responsiveness. Hormones and Behavior 59 180-186. (doi:10.1016/j.yhbeh.2010.11.008)

Bale TL, Anderson KR, Roberts AJ, Lee KF, Nagy TR \& Vale WW 2003 Corticotropin releasing factor receptor-2-deficient mice display abnormal homeostatic response to challenges of increased dietary fat and cold. Endocrinology 144 2580-2587. (doi:10.1210/en.2002-0091)

Behan DP, Linton EA \& Lowry PJ 1989 Isolation of the human plasma corticotropin-releasing factor-binding protein. Journal of Endocrinology 122 22-31. (doi:10.1677/joe.0.1220023)

Bilezikjian LM \& Vale WW 1983 Glucocorticoids inhibit corticotropinreleasing factor-induced production of adenosine $3^{\prime}, 5^{\prime}$-monophosphate in cultured anterior pituitary cells. Endocrinology $\mathbf{1 1 3}$ 657-662. (doi:10.1210/endo-113-2-657)

Bittencourt JC \& Sawchenko PE 2000 Do centrally administered neuropeptides access cognate receptors? An analysis in the central corticotropin-releasing factor system Journal of Neuroscience 20 1142-1156.

Bittencourt JC, Vaughan J, Arias C, Rissman RA, Vale WW \& Sawchenko PE 1999 Urocortin expression in rat brain: evidence against a pervasive relationship of urocortin-containing projections with targets bearing type 2 CRF receptors. Journal of Comparative Neurology 415 285-312. (doi:10. 1002/(SICI) 1096-9861(19991220)415:3 < 285::AID-CNE1 > 3.0.CO;2-0)

Boorse GC, Crespi EK, Dautzenberg FM \& Denver RJ 2005 Urocortins of the South American clawed frog, Xenopus laevis: conservation of structure and function in tetrapod evolution. Endocrinology 146 4851-4860. (doi:10.1210/en.2005-0497)

Brar BK, Chen A, Perrin MH \& Vale W 2004 Specificity and regulation of extracellularly regulated kinase $1 / 2$ phosphorylation through corticotropin-releasing factor (CRF) receptors 1 and $2 \beta$ by the CRF/urocortin family of peptides. Endocrinology 145 1718-1729. (doi:10.1210/en.2003-1023)

Brugge VA, Schooley DA \& Orchard I 2008 Amino acid sequence and biological activity of a calcitonin-like diuretic hormone (DH31) from Rhodnius prolixus. Journal of Experimental Biology 211 382-390. (doi:10.1242/jeb.013771)

Campbell RK, Satoh N \& Degnan BM 2004 Piecing together the evolution of the vertebrate endocrine system. Trends in Genetics 20 359-366. (doi:10.1016/i.tig.2004.06.005)

Cardoso JC, Power DM, Elgar G \& Clark MS 2003 Isolation and characterisation of the corticotropin releasing factor receptor 1 (CRFR1) gene in a teleost fish, Fugu rubripes. DNA Sequence 14 215-218.

Cardoso JC, Pinto VC, Vieira FA, Clark MS \& Power DM 2006 Evolution of secretin family GPCR members in the metazoa. BMC Evolutionary Biology 6 108. (doi:10.1186/1471-2148-6-108)
Catalano RD, Kyriakou T, Chen J, Easton A \& Hillhouse EW 2003 Regulation of corticotropin-releasing hormone type 2 receptors by multiple promoters and alternative splicing: identification of multiple splice variants. Molecular Endocrinology 17 395-410. (doi:10.1210/ me.2002-0302)

Chand D \& Lovejoy DA 2011 Stress and reproduction: controversies and challenges. General and Comparative Endocrinology 171 253-257. (doi:10.1016/j.ygcen.2011.02.022)

Chatzaki E, Murphy BJ, Wang L, Million M, Ohning GV, Crowe PD, Petroski R, Taché Y \& Grigoriadis DE 2004 Differential profiles of CRF receptor distribution in the rat stomach and duodenum assessed by newly developed CRH receptor antibodies. Journal of Neurochemistry $\mathbf{8 8}$ 1-11. (doi:10.1046/j.1471-4159.2003.02078.x)

Chen R, Lewis KA, Perrin MH \& Vale WW 1993 Expression cloning of a human corticotropin-releasing-factor receptor. PNAS 90 8967-8971. (doi:10.1073/pnas.90.19.8967)

Chen AM, Perrin MH, Digruccio MR, Vaughan JM, Brar BK, Arias CM, Lewis KA, Rivier JE, Sawchenko PE \& Vale WW 2005 A soluble mouse brain splice variant of type $2 \alpha$ corticotropin releasing factor (CRF) receptor binds ligands and modulates their activity. PNAS 102 2620-2625. (doi:10. 1073/pnas.0409583102)

Cheng H, Zhou L, Zhu W, Wang A, Tang C, Chan O, Sherwin RS \& McCrimmon RJ 2007 Type 1 corticotropin releasing factor receptors (CRFR1) in the ventromedial hypothalamus (VMH) hypoglycemiainduced hormonal counter regulation. American Journal of Physiology. Endocrinology and Metabolism 293 E705-E712. (doi:10.1152/ajpendo. 00136.2007)

Christie AE, Stevens JS, Bowers MR, Chapline MC, Jensen DA, Schegg KM, Goldwaser J, Kwiatkowski MA, Pleasant TK Jr, Shoenfeld L et al. 2010 Identification of a calcitonin-like diuretic hormone that functions as an intrinsic modulator of the American lobster, Homarus americanus, cardiac neuromuscular system. Journal of Experimental Biology $\mathbf{2 1 3}$ 118-127. (doi:10.1242/jeb.037077)

Coast GM 1998 Insect diuretic peptides; structures, evolution and actions. American Zoologist 38 422-449.

Coast G 2007 The endocrine control of salt balance in insects. General and Comparative Endocrinology 152 332-338. (doi:10.1016/j.ygcen. 2007.02.018)

Coast GM, Webster SG, Schegg KM, Zhang J, Tobe SS \& Schooley DA 2001 The Drosophila melanogaster homoloue of an insect calcitonin-like diuretic peptide stimulates V-ATPase activity in fruit fly Malphigian tubule. Journal of Experimental Biology 204 1795-1804.

Coste SC, Kesterson RA, Heldwein KA, Stevens SL, Heard AD, Hollis JH, Murray SE, Hill JK, Pantely GA, Hohimer AR et al. 2000 Abnormal adaptations to stress and impaired cardiovascular function in mice lacking the corticotropin-releasing hormone receptor-2. Nature Genetics 24 403-409. (doi:10.1038/74255)

Coste SC, Heard AD, Phillips TJ \& Stenzel-Poore MP 2006 Corticotropinreleasing factor receptor type 2-deficient mice display impaired coping behaviors during stress. Genes, Brain, and Behavior 5 131-138. (doi:10.1111/j.1601-183X.2005.00142.x)

Czimmer J, Million M \& Tache Y 2006 Urocortin 2 acts centrally to delay gastric emptying through sympathetic pathways while CRF and urocortin 1 inhibitory actions are vagal dependent in rats. American Journal of Physiology. Gastrointestinal and Liver Physiology 290 G511-G518. (doi:10.1152/ajpgi.00289.2005)

De Groef B, Van der Geyten S, Darras VM \& Kühn ER 2006 Role of corticotropin-releasing hormone as a thyrotropin-releasing factor in non-mammalian vertebrates. General and Comparative Endocrinology 146 62-68. (doi:10.1016/j.ygcen.2005.10.014)

Dehal P \& Boore JL 2005 Two rounds of whole genome duplication in the ancestral vertebrate. PLoS Biology 3 1700-1708. (doi:10.1371/journal. pbio.0030314)

Delsac F, Brinkman H, Chourrout D \& Philippe H 2006 Tunicates and not cephalochordates are the closest living relatives of vertebrates. Nature 439 965-968. (doi:10.1038/nature04336) 
Denver RJ 1997 Environmental stress as a developmental cue: corticotropin-releasing hormone is a proximate mediator of adaptive phenotypic plasticity in amphibian metamorphosis. Hormones and Behavior 31 169-179. (doi:10.1006/hbeh.1997.1383)

DeSouza EB, Perrin MH, Insel TR, Rivier J, Vale WW \& Kuhar MJ 1984 Corticotropin-releasing factor receptors in rat forebrain: autoradiographic identification. Science 224 1449-1451. (doi:10.1126/science. 6328656)

DeSouza EB, Perrin MH, Whitehouse PJ, Rivier J, Vale WW \& Kuhar MJ 1985 Corticotropin-releasing factor receptors in human pituitary gland: autoradiographic localization. Neuroendocrinology 40 419-422. (doi:10.1159/000124107)

DeSouza EB, Whitehouse PJ, Kuhar MJ, Price DL \& Vale WW 1986 Reciprocal changes in corticotropin-releasing factor (CRF)-like immunoreactivity and CRF receptors in cerebral cortex of Alzheimer's disease. Nature 319 593-595. (doi:10.1038/319593a0)

Doyon C, Gilmour KM, Trudeau VL \& Moon TW 2003 Corticotropinreleasing factor and neuropeptide Y mRNA levels are elevated in the preoptic area of socially subordinate rainbow trout. General and Comparative Endocrinology 133 260-271. (doi:10.1016/S00166480(03)00195-3)

Dunn AJ \& Berridge CW 1990 Physiological and behavioral responses to corticotropin-releasing factor administration: is CRF a mediator of anxiety or stress responses? Brain Research. Brain Research Reviews 15 71-100. (doi:10.1016/0165-0173(90)90012-D)

Eghbal-Ahmadi M, Hatalski CG, Lovenberg TW, Avishai-Eliner S, Chalmers DT \& Baram TZ 1998 The developmental profile of the corticotropin releasing factor receptor (CRF2) in rat brain predicts distinct agespecific functions. Brain Research. Developmental Brain Research $\mathbf{1 0 7}$ 81-90. (doi:10.1016/S0165-3806(98)00002-9)

Evans RT \& Seasholtz AF 2009 Soluble corticotropin-releasing hormone receptor 2alpha splice variant is efficiently translated but not trafficked for secretion. Endocrinology 150 4191-4202. (doi:10.1210/ en.2009-0285)

Fredriksson R, Lagerstrom MC, Lundin LG \& Schioth HB 2003 The G-protein-coupled receptors in the human genome from five main families. Phylogenetic analysis, paralogon groups and fingerprints. Molecular Pharmacology 63 1256-1272. (doi:10.1124/mol.63.6.1256)

Furuya K, Milchak RJ, Schegg KM, Zhang J, Tobe SS, Coast GM \& Schooley DA 2000 Cockroach diuretic hormones: characterization of a calcitoninlike peptide in insects. PNAS 97 6469-6474. (doi:10.1073/pnas.97.12. 6469)

Gao L, Lv C, Xu C, Li Y, Cui X, Gu H \& Ni X $2012 a$ Differential regulation of glucose transporters mediated by CRH receptor type 1 and type 2 in human placental trophoblasts. Endocrinology 153 1464-1471. (doi:10.1210/en.2011-1673)

Gao L, Tao Y, Hu T, Liu W, Xu C, Liu J, You X, Gu H \& Ni X 2012b Regulation of estradiol and progesterone production by CRH-R1 and -R2 is through divergent signaling pathways in cultured human placental trophoblasts. Endocrinology 153 4918-4928. (doi:10.1210/ en.2012-1453)

Gelman A \& Rubin DB 1992 Inference from iterative simulation using multiple sequences. Statistical Science 7 457-511. (doi:10.1214/ss/ 1177011136)

Grace CR, Perrin MH, DiGruccio MR, Miller CL, Rivier JE, Vale WW \& Riek R 2004 NMR structure and peptide hormone binding site of the first extracellular domain of a type B1 G protein-coupled receptor. PNAS 101 12836-12841. (doi:10.1073/pnas.0404702101)

Grammatopoulos DK, Randeva HS, Levine MA, Katsanou ES \& Hillhouse EW 2000 Urocortin, but not corticotropin-releasing hormone (CRH), activates the mitogen-activated protein kinase signal transduction pathway in human pregnant myometrium: an effect mediated via $\mathrm{R} 1 \alpha$ and R2 $\beta$ CRH receptor subtypes and stimulation of Gq-proteins. Molecular Endocrinology 14 2076-2091.

Grammatopoulos DK, Randeva HS, Levine MA, Kanellopoulou KA \& Hillhouse EW 2001 Rat cerebral cortex corticotropin-releasing hormone receptors: evidence for receptor coupling to multiple G-proteins. Journal of Neurochemistry 76 509-519. (doi:10.1046/ j.1471-4159.2001.00067.x)

Grigoriadis DE \& DeSouza EB 1989 Heterogeneity between brain and pituitary corticotropin-releasing factor receptors is due to differential glycosylation. Endocrinology 125 1877-1888. (doi:10.1210/ endo-125-4-1877)

Gue M, Junien JL \& Bueno L 1991 Conditioned emotional response in rats enhances chronic motility through the central release of corticotropin releasing factor. Gastroenterology 100 964-970.

Guillemin R \& Rosenberg B 1955 Humoral hypothalamic control of anterior pituitary: a study with combined tissue cultures. Endocrinology 57 599-607. (doi:10.1210/endo-57-5-599)

Guindon S \& Gascuel O 2003 A simple, fast, and accurate algorithm to estimate large phylogenies by maximum likelihood. Systematic Biology 52 696-704. (doi:10.1080/10635150390235520)

Guindon S, Lethiec F, Duroux P \& Gascuel O 2005 PHYML Online - a web server for fast maximum likelihood-based phylogenetic inference. Nucleic Acids Research 33 W557-W559. (doi:10.1093/nar/gki352)

Guindon S, Dufayard JF, Lefort V, Anisimova M, Hordijk W \& Gascuel O 2010 New algorithms and methods to estimate maximum-likelihood phylogenies: assessing the performance of PhyML 3.0. Systematic Biology 59 307-321. (doi:10.1093/sysbio/syq010)

Gutknecht E, Vauquelin G \& Dautzenberg FM 2010 Corticotropin-releasing factor receptors induce calcium mobilization through cross-talk with Gq-coupled receptors. European Journal of Pharmacology 642 1-9. (doi:10.1016/j.ejphar.2010.05.027)

Hammack SE, Schmid MJ, LoPresti ML, Der-Avakian A, Pellymounter MA, Foster AC, Watkins LR \& Maier SF 2003 Corticotropin releasing hormone type 2 receptors in the dorsal raphe nucleus mediate the behavioral consequences of uncontrollable stress. Journal of Neuroscience 23 1019-1025.

Harmer AJ 2001 Family B G protein coupled receptors. Genome Biology 2 3013.

Hauger RL, Risbrough V, Brauns O \& Dautzenberg FM 2006 Corticotropin releasing factor (CRF) receptor signaling in the central nervous systems: new molecular targets. CNS \& Neurological Disorders Drug Targets 5 453-479. (doi:10.2174/187152706777950684)

Hillhouse EW \& Grammatopoulos DK 2006 The molecular mechanisms underlying the regulation of the biological activity of corticotropinreleasing hormone receptors: implications for physiology and pathology. Endocrine Reviews 27 260-286. (doi:10.1210/er.2005-0034)

Hoare SRJ, Sullivan SK, Schwarz DA, Ling N, Vale WW, Crowe PD \& Grigoriadis DE 2004 Ligand affinity for amino-terminal and juxtamembrane domains of the corticotropin releasing factor type I receptor: regulation by G-protein and nonpeptide antagonists. Biochemistry 43 3996-4011. (doi:10.1021/bi036110a)

Holland PW 1999 Gene duplication: past, present and future. Seminars in Cell \& Developmental Biology 10 541-547. (doi:10.1006/scdb.1999.0335)

Holland PW, Garcia-Fernandez J, Williams NA \& Sidow A 1994 Gene duplications and the origins of vertebrate development. Development. Supplement. 125-133.

Hsu SY \& Hseuh AJW 2001 Human stresscopin and stresscopin related peptide are selective ligands for the type 2 corticotropin releasing hormone receptor. Nature Medicine 7 605-611. (doi:10.1038/87936)

Huising MO \& Flik G 2005 The remarkable conservation of corticotropinreleasing hormone $(\mathrm{CRH})$ binding protein in the honeybee (Apis mellifera) dates the CRF system to a common ancestor to insects and vertebrates. Endocrinology 146 2165-2170. (doi:10.1210/en.2004-1514)

Huising MO, Metz JR, van Schooten C, Taverne-Thiele AJ, Hermsen T, Verburg-van Kemenade BM \& Flik G 2004 Structural characterisation of a cyprinid (Cyprinus carpio L.) CRH, CRH-BP and CRH-R1, and the role of these proteins in the acute stress response. Journal of Molecular Endocrinology 32 627-648. (doi:10.1677/jme.0.0320627)

Ikemoto T \& Park MK 2006 Comparative genomics of the endocrine system in humans and chimpanzees with special reference to GnRH 2 and

Published by Bioscientifica Ltd 
UCN2 and their receptors. Genomics 87 459-462. (doi:10.1016/j.ygeno. 2005.11.005)

Janssen D \& Kozicz T 2013 Is it really a matter of simple dualism? Corticotropin-releasing factor receptors in body and mental health Frontiers in Endocrinology 4 1-12. (doi:10.3389/fendo.2013.00028)

Kataoka H, Troetschler RG, Li JP, Kramer SJ, Carney RL \& Schooley DA 1989 Isolation and identification of a diuretic hormone from the tobacco hornworm, Manduca sexta. PNAS 86 2976-2980. (doi:10.1073/pnas.86. 8.2976)

Kellow JE, Langeluddecke PM, Eckersley GM, Jones MP \& Tennant CC 1992 Effects of acute psychological stress on small intestinal motifility in health and the irritable bowel syndrome. Scandinavian Journal of Gastroenterology 27 53-58. (doi:10.3109/00365529209011167)

Kelsall CJ \& Balment RJ 1998 Native urotensins influence cortisol secretion and plasma cortisol concentration in the euryhaline flounder, Platichthys flesus. General and Comparative Endocrinology 112 210-219. (doi:10.1006/gcen.1998.7166)

Kiapekou E, Zapanti E, Voukelatou D, Mavreli T, Stefanidis K, Drakakis P, Mastorakos G \& Loutradis D 2011 Corticotropin-releasing hormone inhibits in vitro oocyte maturation in mice. Fertility and Sterility $\mathbf{9 5}$ 1497-1499. (doi:10.1016/j.fertnstert.2010.12.023)

Kinsey-Jones JS, Li XF, Knox AM, Lin YS, Milligan SR, Lightman SL \& O'Byrne KT 2010 Corticotrophin-releasing factor alters the timing of puberty in the female rat. Journal of Neuroendocrinology 22 102-109. (doi:10.1111/j.1365-2826.2009.01940.x)

Kishimoto T, Pearse RV II, Lin CR \& Rosenfeld MG 1995 A sauvagine/ corticotropin-releasing factor receptor expressed in heart and skeletal muscle. PNAS 92 1108-1112. (doi:10.1073/pnas.92.4.1108)

Koob GF \& Heinrichs SC 2004 Corticotropin-releasing factor in the brain: a role in activation, arounsal and affect regulation. Journal of Pharmacology and Experimental Therapeutics 311 427-440. (doi:10.1124/ ipet.103.052092)

Kuperman Y \& Chen A 2008 Emerging metabolic and energy homeostasis perspectives. Trends in Endocrinology and Metabolism 19 122-129. (doi:10.1016/j.tem.2007.12.002)

Kwon H, Lu HL, Longnecker MT \& Pietrantonio PV 2012 Role of diuresis of a calcitonin receptor (GPCRCAL1) expressed in a distal-proximal gradient in renal organs of the mosquito, Aedes aegypti (L). PLOS ONE 11 e50374. (doi:10.1371/journal.pone.0050374)

Labrie F, Veilleux R, Lefevre G, Coy DH, Sueiras-Diaz J \& Schally AV 1982 Corticotropin-releasing factor stimulates accumulation of adenosine $3^{\prime}, 5^{\prime}$-monophosphate in rat pituitary corticotrophs. Science $\mathbf{2 8}$ 1007-1008. (doi:10.1126/science.6281886)

Larkin MA, Blackshields G, Brown NP, Chenna R, McGettigan PA, McWilliam H, Valentin F, Wallace IM, Wilm A, Lopez R et al. 2007 Clustal W and Clustal X version 2.0. Bioinformatics 23 2947-2948. (doi:10.1093/bioinformatics/btm404)

Lastein S, Höglund E, Overli O \& Døving KB 2008 Effects of antalarmin, a CRF receptor 1 antagonist, on fright reaction and endocrine stress response in crucian carp (Carassius carassius). Journal of Comparative Physiology. A, Neuroethology, Sensory, Neural, and Behavioral Physiology. 194 1007-1012. (doi:10.1007/s00359-008-0372-9)

Le SQ \& Gascuel O 2008 An improved general amino acid replacement matrix. Molecular Biology and Evolution 25 1307-1320. (doi:10.1093/ molbev/msn067)

Lederis K, Letter A, McMaster D, Moore G \& Schlesinger D 1982 Complete amino acid sequence of urotensin-I, a hypotensive and corticotropinreleasing neuropeptide from Catostomus. Science 218 162-164. (doi:10.1126/science.6981844)

Lederis K, Fryer J, Rivier J, MacCannell KL, Kobayashi Y, Woo N \& Wong KL 1985 Neurohormones from fish tails II: actions of urotensin-I in mammals and fishes. Recent Progress in Hormone Research 41 553-576.

Lee KH, Bishop GA, Tian JB, Jang YJ, Bui BC, Nguyen Tle X, Ahn JY \& King JS 2007 Cellular localization of the full-length isoform of the type 2 corticotropin releasing factor receptor in the postnatal mouse cerebellar cortex. Journal of Neuroscience Research 85 1996-2005. (doi:10.1002/jnr.21333)

Le Mevel JC, Mimassi N, Lancien F, Mabin D \& Conlon JM 2006 Cardiovascular actions of the stress-related neurohormonal peptides, corticotropin-releasing factor and urotensin-I in the trout Oncorhynchus mykiss. General and Comparative Endocrinology 146 56-61. (doi:10.1016/ j.ygcen.2005.11.007)

Lewis K, Li C, Perrin MH, Flound A, Kunitake K, Donaldson C, Vaughan J, Reyes TM, Gulyas J, Fischer W et al. 2001 Identification of urocortin III and additional member of the corticotropin releasing factor family with high affinity for the CRF2 receptor. PNAS 98 7570-7575. (doi:10.1073/pnas.121165198)

Li XF, Knox AM \& O'Byrne KT 2010 Corticotrophin-releasing factor and stress-induced inhibition of the gonadotrophin-releasing hormone pulse generator in the female. Brain Research 1364 153-163. (doi:10.1016/j.brainres.2010.08.036)

Li C, Chen M, Sang M, Liu X, Wu W \& Li B 2013 Comparative genomic analysis and evolution of family B-G protein coupled receptors from six model insect species. Gene 519 1-12. (doi:10.1016/j.gene.2013.01.061)

Liaw CW, Lovenberg TW, Barry G, Oltersdorf T, Grigoriadis DE \& de Souza EB 1996 Cloning and characterization of the human corticotropinreleasing factor-2 receptor complementary deoxyribonucleic acid. Endocrinology 137 72-77.

Lovejoy DA 2005 In Neuroendocrinology: An Integrated Approach, pp 50-52. Chichester, UK: John Wiley and Sons.

Lovejoy DA 2009 Structural evolution of urotensin-I: retaining ancestral functions before corticotropin-releasing hormone evolution. General and Comparative Endocrinology 164 15-19. (doi:10.1016/j.ygcen.2009. 04.014)

Lovejoy DA 2012 Corticotrophin-releasing hormone. In Handbook of Biologically Active Peptides, 2nd edn, pp 752-759. Ed A Kastin. San Diego, CA, USA: Academic Press.

Lovejoy DA \& Balment RJ 1999 Evolution and physiology of the corticotropin-releasing factor (CRF) family of neuropeptides in vertebrates. General and Comparative Endocrinology 115 1-22. (doi:10.1006/gcen.1999.7298)

Lovejoy DA \& Barsyte D 2011 In Sex, Stress and Reproductive Success, p 250. Chichester, UK: John Wiley and Sons.

Lovejoy DA \& Barsyte-Lovejoy D 2010 Characterization of a diuretic hormone-like peptide from tunicates: insight into the origins of the vertebrate corticotropin-releasing factor (CRF) family. General and Comparative Endocrinology 165 330-336. (doi:10.1016/j.ygcen.2009. 07.013)

Lovejoy DA \& de Lannoy L 2013 Evolution and phylogeny of the corticotropin-releasing factor (CRF) family of peptides: expansion and specialization in the vertebrates. Journal of Chemical Neuroanatomy $\mathbf{5 4}$ 50-56. (doi:10.1016/j.jchemneu.2013.09.006)

Lovejoy DA \& Jahan S 2006 Phylogeny and evolution of the corticotropin releasing factor family of peptides. General and Comparative Endocrinology 146 1-8. (doi:10.1016/j.ygcen.2005.11.019)

Lovenberg TW, Liaw CW, Grigoriadis DE, Clevenger W, Chalmers DT, De Souza EB \& Oltersdorf T 1995 Cloning and characterization of a functionally distinct corticotropin-releasing factor receptor subtype from rat brain. PNAS 92 836-840. (doi:10.1073/pnas.92.3.836)

Lundin LG 1993 Evolution of the vertebrate genome as reflected in paralogous chromosomal regions in man and the house mouse. Genomics 16 1-19. (doi:10.1006/geno.1993.1133)

Madtes PC Jr \& King JS 1996 The temporal and spatial development of corticotropin-releasing factor (CRF) binding sites and CRF afferents in the opossum cerebellum. Journal of Chemical Neuroanatomy 11 231-241. (doi:10.1016/S0891-0618(96)00164-0)

Makino S, Asaba K, Nishiyama M \& Hashimoto K 1999 Decreased type 2 corticotropin releasing hormone receptor mRNA expression in the ventromedial hypothalamus during repeated immobilization to stress. Neuroendocrinology 70 160-167. (doi:10.1159/000054472) 
Manzon RG \& Denver RJ 2004 Regulation of the pituitary thyropin gene expression during Xenopus metamorphosis: negative feedback is functional throughout metamorphosis. Journal of Endocrinology 182 273-285. (doi:10.1677/joe.0.1820273)

Martinez V, Wang L, Rivier J, Grigoriadis D \& Tache Y 2004 Central CRF urocortins and stress increase colonic transit via CRF1 receptors while activation of CRF2 receptors delays gastric transit in mice. Journal of Physiology 556 221-234. (doi:10.1113/jphysiol.2003.059659)

Mazon AF, Verburg-van Kemenade BM, Flik G \& Huising MO 2006 Corticotropin-releasing hormone-receptor 1 (CRH-R1) and CRHbinding protein (CRH-BP) are expressed in the gills and skin of common carp Cyprinus carpio L. and respond to acute stress and infection. Journal of Experimental Biology 209 510-517. (doi:10.1242/ jeb.01973)

Mitchell AJ 1998 The role of corticotropin releasing factor in depressive illness: a critical review. Neuroscience and Biobehavioral Reviews 22 635-651. (doi:10.1016/S0149-7634(97)00059-6)

Montecucchi PA, Neschen A \& Erspamer V 1979 Structure of sauvagine, as vasoactive peptide from the skin of a frog. Hoppe-Seyler's Z. Physiological Chemistry 3601178.

Morley SD, Schonrock C, Richter D, Okawara Y \& Lederis K 1991 Corticotropin-releasing factor (CRF) gene family in the brain of the teleost fish Catostomus commersoni (white sucker): molecular analysis predicts distinct precursors for two CRF's and one urotensin I peptide. Molecular Marine Biology and Biotechnology 1 48-57.

Muller MG, Preil J, Renner U, Zimmermann S, Kresse AE, Stalla GK, Keck ME, Holsboer F \& Wurst W 2001 Expression of CRHR1 and CRHr2 in mouse pituitary and adrenal gland: implication for HPA system regulation. Endocrinology 142 4150-5153. (doi:10.1210/endo.142.9.8491)

Mulley JF, Zhong YF \& Holland PWH 2009 Comparative genomics of chondrichthyan Hoxa clusters. BMC Evolutionary Biology 9 e218. (doi:10.1186/1471-2148-9-218)

Mungpakdee HC, Seo AR, Angotzi X, Dong A, Akalin D \& Chourrout P 2008 Differential evolution of the thirteen atlantic salmon Hox clusters. Molecular Biology and Evolution 25 1333-1343. (doi:10.1093/molbev/ msn097)

Nappi RE \& Rivest S 1995 Stress induced genetic expression of a selective corticotropin releasing factor receptor subtype within the rat ovarian cycle. Biology of Reproduction 53 1417-1428. (doi:10.1095/biolreprod53. 6.1417)

Nishimura E, Billestrup N, Perrin M \& Vale W 1987 Identification and characterization of a pituitary corticotropin-releasing factor binding protein by chemical cross-linking. Journal of Biological Chemistry $\mathbf{2 6 2}$ 12893-12896.

Nock TG, Chand D \& Lovejoy DA 2011 Identification of members of the gonadotropin-releasing hormone $(\mathrm{GnRH})$, corticotropin-releasing factor (CRF) families in the genome of the holocephalan, Callorhinchus milii (elephant shark). General and Comparative Endocrinology 171 237-244. (doi:10.1016/j.ygcen.2011.02.001)

Okada R, Miller MF, Yamamoto K, De Groef B, Denver RJ \& Kikuyama S 2007 Involvement of the corticotropin-releasing factor (CRF) type 2 receptor in CRF-induced thyrotropin release by the amphibian pituitary gland. General and Comparative Endocrinology 150 437-444. (doi:10.1016/j.ygcen.2006.11.002)

Olianas MC, Lampis G \& Onali P 1995 Human Y-79 retinoblastoma cells exhibit specific corticotropin-releasing hormone binding sites. Journal of Neurochemistry 64 394-401. (doi:10.1046/j.1471-4159.1995. 64010394.X)

Oshida Y, Ikeda Y, Chaki S \& Okuyama S 2004 Monkey corticotropinreleasing factor 1 receptor: complementary DNA cloning and pharmacological characterization. Life Sciences 74 1911-1924. (doi:10.1016/j.lfs.2003.08.035)

Perrin MH \& Vale W 2002 Understanding G-protein coupled receptors and their role in the CNS, pp 505-526. Eds MN Pangalos \& CH Davies. New York: Oxford University Press.
Perrin MH, Haas Y, Rivier JE \& Vale WW 1986 Corticotropin-releasing factor binding to the anterior pituitary receptor is modulated by divalent cations and guanyl nucleotides. Endocrinology 118 1171-1179. (doi:10.1210/endo-118-3-1171)

Perrin M, Donaldson C, Chen R, Blount A, Berggren T, Bilezikjian L, Sawchenko P \& Vale W 1995 Identification of a second corticotropinreleasing factor receptor gene and characterization of a cDNA expressed in heart. PNAS 92 2969-2973. (doi:10.1073/pnas.92.7.2969)

Platzack B, Schaffert C, Hazon J \& Conlon JM 1998 Cardiovascular actions of dogfish urotensin-I in the dogfish, Scyliorhinus canicula. General and Comparative Endocrinology 109 269-275. (doi:10.1006/gcen.1997.7030)

Pohl S, Darlison MG, Clarke WC, Lederis K \& Richter D 2001 Cloning and functional pharmacology of two corticotropin-releasing factor receptors from a teleost fish. European Journal of Pharmacology $\mathbf{4 3 0}$ 193-202. (doi:10.1016/S0014-2999(01)01391-7)

Potter E, Behan DP, Fischer WH, Linton EA, Lowry PJ \& Vale WW 1991 Cloning and characterization of the cDNA's for human and rat corticotropin releasing factor binding protein. Nature 349 423-426. (doi:10.1038/349423a0)

Refojo D, Schweizer M, Kuehne C, Ehrenberg S, Thoeringer C, Vogl AM, Dedic N, Schumacher M, von Wolff G, Avrabos C et al. 2011 Glutamatergic and dopaminergic neruons mediate anxiolytic effects of CRHR1. Science 355 1905-1907.

Reyes TM, Lewis K, Perrin MH, Kunitake KS, Vaughan J, Arias CA, Hogenesch JB, Gulyas J, Rivier J, Vale WW et al. 2001 Urocortin II: a member of the corticotropin releasing factor (CRF) neuropeptide family that is selectively bound by type 2 receptors. PNAS $\mathbf{9 8}$ 2843-2848. (doi:10.1073/pnas.051626398)

Risbrough VB \& Stein MB 2006 A role of corticotropin releasing factor in anxiety disorders: a translational research perspective. Hormones and Behavior 50 550-561. (doi:10.1016/j.yhbeh.2006.06.019)

Ronquist F \& Huelsenbeck JP 2003 MrBayes 3: Bayesian phylogenetic inference under mixed models. Bioinformatics 19 1572-1574. (doi:10.1093/bioinformatics/btg180)

Rosendale BE, Jarrett DB \& Robinson AG 1987 Identification of a corticotropin-releasing factor-binding protein in the plasma membrane of AtT-20 mouse pituitary tumor cells and its regulation by dexamethasone. Endocrinology 120 2357-2366. (doi:10.1210/ endo-120-6-2357)

Rotzinger S, Lovejoy DA \& Tan LA 2010 Behavioral effects of neuropeptides in rodent models of depression and anxiety. Peptides 31 736-756. (doi:10.1016/j.peptides.2009.12.015)

Sakai K, Yamada M, Horiba N, Wakui M, Demura H \& Suda T 1998 The genomic organization of the human corticotropin-releasing factor type-1 receptor. Gene 219 125-130. (doi:10.1016/S03781119(98)00322-9)

Schally AV \& Saffran M 1955 The release of corticotrophin by anterior pituitary tissue in vitro. Canadian Journal of Physiology and Pharmacology 33 408-415.

Selye H 1950 In Stress, 1st edn. Montreal, Canada: Acta, Inc.

Sherwood NM, Tello JA \& Roch GJ 2006 Neuroendocrinology of protochordates: insights from Ciona genomics. Comparative Biochemistry and Physiology. Part A, Molecular \& Integrative Physiology 144 254-271. (doi:10.1016/j.cbpa.2005.11.013)

Slominiski A, Ermak G, Hwang J, Chakravorty AM, Mazurkiekiewicz JE \& Mihm M 1995 Proopiomelanocortin, corticotropin releasing hormone and corticotropin releasing hormone receptor genes are expressed in human skin. FEBS Letters 374 113-116. (doi:10.1016/00145793(95)01090-2)

Smith GW, Aubry JM, Dellu F, Contarino A, Bileikjian LM, Gold LH, Chen R, Marchuk Y, Hauser C, Bentley CA et al. 1998 Stress response and aberrant neuroendocrine development. Neuron 20 1093-1102. (doi:10.1016/S0896-6273(00)80491-2)

Spina M, Merlo-Pich E, Chan KW, Basso AM, Rivier J, Vale W \& Koob G 1996 Appetite-suppressing effects of urocortin, a CRF-related peptide. Science 273 1561-1564. (doi:10.1126/science.273.5281.1561) 
Stenzel P, Kesterson R, Yeung W, Cone RD, Rittenberg MB \& Stenzel-Poore MP 1995 Identification of a novel murine receptor for corticotropinreleasing hormone expressed in the heart. Molecular Endocrinology 9 637-645.

Sutton SW, Behan DP, Lahrichi SL, Kaiser R, Corrigan A, Lowry P, Potter E, Perrin M, Rivier J \& Vale WW 1995 Ligand requirements of the human corticotropin-releasing factor binding protein. Endocrinology 136 1097-1102.

Squillacioti C, De Luca A, Liguori G, Paino S \& Mirabella N 2011 Expression of urocortin and corticotropin-releasing hormone receptors in the bovine adrenal gland. General and Comparative Endocrinology 172 416-422. (doi:10.1016/j.ygcen.2011.04.004)

Squillacioti C, De Luca A, Alì S, Paino S, Liguori G \& Mirabella N 2012 Expression of urocortin and corticotropin-releasing hormone receptors in the horse thyroid gland. Cell and Tissue Research 350 45-53. (doi:10.1007/s00441-012-1450-4)

Tache Y \& Bonaz B 2007 Corticotropin-releasing factor receptors and stress-related alterations of gut motor function. Journal of Clinical Investigations 117 33-40. (doi:10.1172/JCI30085)

Tache Y, Martinez V, Million M \& Wang L 2001 Stress and the gastrointestinal tract. III Stress-related alterations of the the gut motor function: role of brain corticotropin-releasing factor receptors. American Journal of Physiology. Gastrointestinal and Liver Physiology 280 G173-G177.

Tellam DJ, Mohammad YN \& Lovejoy DA 2000 Molecular integration of hypothalamo-pituitary-adrenal axis-related neurohormones on the GnRH neuron. Biochemistry and Cell Biology 78 205-216. (doi:10.1139/ o00-060)

Tellam DJ, Smart D, Qian X \& Lovejoy DA 2002 A synthetic chimaeric sauvagine-like peptide with corticotropin-releasing factor (CRF)-R2 receptor selective agonism: a model for receptor-ligand coevolution. Journal of Peptide Research 60 215-222. (doi:10.1034/j.1399-3011.2002. 21024.x)

Thompson JD, Higgins DG \& Gibson TJ 1994 CLUSTAL W: improving the sensitivity of progressive multiple sequence alignment through sequence weighting, position-specific gap penalties and weight matrix choice. Nucleic Acids Research 22 4673-4680. (doi:10.1093/nar/22.22. 4673)

Tsai-Morris CH, Buczko E, Geng Y, Gamboa-Pinto A \& Dufau ML 1996 The genomic structure of the rat corticotropin releasing factor receptor. A member of the class II G protein-coupled receptors. Journal of Biological Chemistry 271 14519-14525. (doi:10.1074/jbc.271.24.14519)

Ulloa-Aguirre A, Stanislaus D, Janovick JA \& Conn PM 1999 Structureactivity relationships of G protein-coupled receptors. Archives of Medical Research 30 420-435. (doi:10.1016/S0188-0128(99)00041-X)

Vale W, Spiess J, Rivier C \& Rivier J 1981 Characterization of a 41-residue ovine hypothalamic peptide that stimulates secretion of corticotropin and b-endorphin. Science 213 1394-1397. (doi:10.1126/science. 6267699)

Valverde RA, Seasholtz AF, Cortright DN \& Denver RJ 2001 Biochemical characterization and expression analysis of the Xenopus laevis corticotropin releasing hormone binding protein. Molecular and Cellular Biology 173 28-40.

Van Pett K, Viau V, Bittencourt JC, Chan RK, Li HY, Arias C, Prins GS, Perrin M, Vale W \& Sawchenko PE 2000 Distribution of mRNAs encoding CRF receptors in brain and pituitary of rat and mouse. Journal of Comparative Neurology 428 191-212. (doi:10.1002/1096-9861(20001211)428:2< 191::AID-CNE1 > 3.0.CO;2-U)

Vaughan J, Donaldson C, Bittencourt J, Perrin MH, Lewis K, Sutton S, Chan R, Turnbull AV, Lovejoy DA, Sawchenko PE et al. 1995 Characterization of urocortin, a novel mammalian neuropeptide related to fish urotensin-I and to CRF. Nature 378 287-292. (doi:10.1038/378287a0)

Veenstra JA, Rombauts S \& Grbic M 2012 In silico cloning of genes encoding neuropeptides, neurohormones and their putative G-protein couple receptors in a spider mite. Insect Biochemistry and Molecular Biology $\mathbf{4 2}$ 277-295. (doi:10.1016/j.ibmb.2011.12.009)

Willenberg HS, Haase M, Papewalis C, Schott M, Scherbaum WA \& Bornstein SR 2006 Corticotropin-releasing hormone receptor expression on normal and tumorous human adrenocortical cells. Neuroendocrinology 82 274-281. (doi:10.1159/000093126)

Williams CL, Peterson JM, Villar RG \& Burks TF 1987 Corticotropinreleasing factor directly mediates chronic responses to stress. American Journal of Physiology 252 G582-G586.

Wolfe KH 2001 Yesterday's polyploids and the mystery of diploidization. Nature Reviews. Genetics 2 333-341. (doi:10.1038/35072009)

Wynn PC, Aguilera G, Morell J \& Catt KJ 1983 Properties and regulation of high-affinity pituitary receptors for corticotropin-releasing factor. Biochemical and Biophysical Research Communications 110 602-608. (doi:10.1016/0006-291X(83)91192-0)

Xu J, Xu F, Hennebold JD, Molskness TA \& Stouffer RL 2007 Expression and role of the corticotropin-releasing hormone/urocortin-receptorbinding protein system in the primate corpus luteum during the menstrual cycle. Endocrinology 148 5385-5395. (doi:10.1210/ en.2007-0541)

Zandawala M 2012 Calcitonin-like diuretic hormones in insects. Insect Biochemistry and Molecular Biology 42 816-825. (doi:10.1016/j.ibmb. 2012.06.006)

Zandawala M, Paluzzi JP \& Orchard I 2011 Isolation and characterization of the cDNA encoding DH(31) in the kissing bug, Rhodnius prolixus. Molecular and Cellular Endocrinology 331 79-88. (doi:10.1016/j.mce. 2010.08.012)

Zorrilla EP, Taché Y \& Koob GF 2003 Nibbling at CRH receptor control of feeding and gastrocolonic motility. Trends in Pharmacological Sciences 24 421-427. (doi:10.1016/S0165-6147(03)00177-9)

Received in final form 27 February 2014

Accepted 3 April 2014

Accepted Preprint published online 7 April 2014 http://jme.endocrinology-journals.org DOI: 10.1530/JME-13-0238
(C) 2014 Society for Endocrinology Printed in Great Britain
Published by Bioscientifica Ltd 